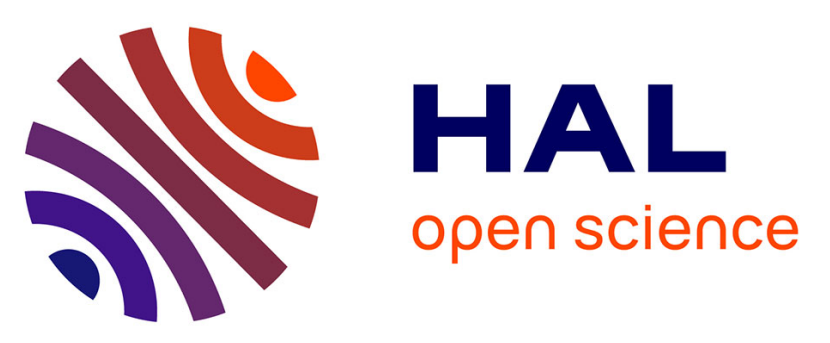

\title{
Impact of erosion and décollements on large-scale faulting and folding in orogenic wedges: analogue models and case studies
}

Clement Perrin, Luca Clemenzi, Jacques Malavieille, Giancarlo Molli, Alfredo Taboada, Stéphane Dominguez

\section{To cite this version:}

Clement Perrin, Luca Clemenzi, Jacques Malavieille, Giancarlo Molli, Alfredo Taboada, et al.. Impact of erosion and décollements on large-scale faulting and folding in orogenic wedges: analogue models and case studies. Journal of the Geological Society, 2013, 170 (6), pp.893-904. 10.1144/jgs2013-012 . hal-03519254

\section{HAL Id: hal-03519254 \\ https://hal.science/hal-03519254}

Submitted on 10 Jan 2022

HAL is a multi-disciplinary open access archive for the deposit and dissemination of scientific research documents, whether they are published or not. The documents may come from teaching and research institutions in France or abroad, or from public or private research centers.
L'archive ouverte pluridisciplinaire HAL, est destinée au dépôt et à la diffusion de documents scientifiques de niveau recherche, publiés ou non, émanant des établissements d'enseignement et de recherche français ou étrangers, des laboratoires publics ou privés. 

8

\section{Impact of erosion and décollements on}

large scale faulting and folding in orogenic wedges: analogue models and case studies

\section{Clément Perrin $^{\text {a, d,*, Luca Clemenzi }}{ }^{\text {a, b, c }}$, Jacques Malavieille ${ }^{\text {a }}$,}

Giancarlo Molli ${ }^{\text {b }}$, Alfredo Taboada ${ }^{\text {a }}$ and Stéphane Dominguez ${ }^{\text {a }}$

${ }^{\text {a }}$ Géosciences Montpellier, Université Montpellier 2, Place E. Bataillon, 34095 Montpellier cedex 5, France

${ }^{\mathrm{b}}$ Dipartimento di Scienze della Terra, Università di Pisa, Via S.Maria, 53, 56126 Pisa, Italy

${ }^{\mathrm{c}}$ Dipartimento di Fisica e Scienze della Terra, Università degli Studi di Parma, Parco Area delle Scienze, 157/A 43100 Parma, Italy

${ }^{\mathrm{d}}$ Géoazur, Université de Nice-Sophia Antipolis, Centre National de la Recherche Scientifique (UMR 7329), Observatoire de la Côte d'Azur, 250 av Albert Einstein, 06560 Valbonne, France

* Corresponding author. Present address: Géoazur. Université de Nice-Sophia Antipolis, Bât 4, 250 av Albert Einstein, Les Lucioles 1, Sophia-Antipolis 06560 Valbonne, France. Tel.: +33 (0)4 83618682 / Fax: +33 (0)4 92942610 . E-mail address: clement.perrin@geoazur.unice.fr (C. Perrin)

5876 words (without references and captions); 114 references; 1 table; 10 figures; 2 figures in supplementary material Running title : Modeling erosional fold and thrust belts 
28 Abstract: Deformation mechanisms, long-term kinematics and evolution of fold and

29 thrust belts submitted to erosion are studied through $2 \mathrm{D}$ analog experiments involving 30 large convergence. First order parameters tested include: i) décollements and/or 31 plastic layers interbedded at different location within analog materials; ii) 32 synconvergence surface erosion.

33 Weak layers, depending on their location in the model, favor deformation partitioning 34 characterized by the simultaneous development of: i) underplating domains in the 35 inner part of the wedge (basal accretion); ii) frontal accretion where the wedge grows 36 forward. Interaction between tectonics and surface processes influence this behavior. 37 Development of antiformal thrust stacks controlled by underplating show small- and 38 large-scale cyclicity.

39 Thin plastic layers induce folding processes, which are studied at wedge scale. 40 Recumbent and overturned folds, with large inverted limbs, develop in shear induced 41 asymmetric deformation regime via progressive unrolling of synclinal hinges. Surface 42 erosion and underplating at depth induce further rotation (passive tilting) and 43 horizontalization of fold limbs.

44 Models results give insights to discuss the mechanisms responsible for the large-scale 45 structures (i.e., antiformal nappe stacks, klippen and kilometer scale recumbent fold46 nappes) encountered in several mountain belts such as the Montagne Noire (French 47 Massif Central), the Galicia Variscan belt (Spain) or the Northern Apennines (Italy). 
52 Orogenic wedges are characterized by complex geological structures growing and 53 evolving over long time periods (e.g. Fossen 2010). Their building is mainly 54 controlled by the general mechanics of subduction and by the interactions between 55 tectonics and surface processes that modify wedge dynamics through material transfer 56 (e.g. Malavieille 2010). Because subduction orogens suffer large convergence, the 57 long-term deformation is intense and generates specific structures which mechanisms 58 of genesis are still not completely understood. Among them, the way large-scale recumbent fold-nappes observed in several mountain belt forelands grow and evolve remains enigmatic (Fig. 1). The most beautiful examples in Europe are situated in the

61 Montagne Noire (Southern French Massif Central), Galicia Mountain Belt, (Spain) or 62 the Northern Appennines (Italy). For example, during the Variscan Orogen, largescale fold-nappes with huge inverted limbs (sometime of more than ten kilometers of amplitude) have been created without (or with very low) metamorphism (e.g. Matte 1968; Arthaud 1970). Other large scale structures are common in mountain belts, such as antiformal stacks of thrust units and subsequent frontal klippen which can be

67 sometimes related to deformation partitioning and subsequent basal accretion of duplex structures (e.g. Elliott \& Johnson 1980; Price 1981; Platt et al. 1985; Hatcher 1989; Gutscher et al. 1996; Burkhard \& Sommaruga 1998; Mosar 1999; Kukowski et al. 2002; Avouac 2003; Malavieille 2010; Konstantinovskaia \& Malavieille 2011;

71 Long et al. 2011; Webb et al. 2011). Basal accretion activity is generally not constant 72 during the long-term convergent history of orogenic wedges, alternating 73 underthrusting of new tectonic slices with the internal deformation of the already 74 accreted ones, or even with the migration of the underplating locus to a new place. 75 Such a cyclical underplating behavior could promote, at a whole wedge scale, an 76 alternate change from supercritical to subcritical taper condition, in turn favoring 
alternations between horizontal and vertical shortening observed in many orogens (e.g. Bell \& Johnson, 1989; Bell \& Sapkota 2012; Aerden et al. 2013). What mechanisms control large scale folding, basal accretion and its cyclicity remain an open question.

Analog modeling is an efficient tool to unravel the main mechanisms controlling the dynamics of orogenic wedges. Various experimental studies have investigated the influence of geometrical, kinematical and rheological parameters on the evolution of thrust wedges (see a review in Graveleau et al. 2012). One of the most important parameter highlighted is the layering of the accreting crustal materials that induces mechanical heterogeneity and deformation partitioning. Such a heterogeneous rheology of accreted rock sequences is the result of various factors: stratigraphy of the incoming crustal layer (e.g. Davis \& Engelder 1985; Mulugeta 1988; Liu \& Dixon 1990; Liu et al. 1992; Baby et al. 1995; Mandal et al. 1997; Nieuwland et al. 2000; Costa \& Vendeville 2002; Koyi \& Vendeville 2003; Konstantinovskaia \& Malavieille 2005; Stockmal et al. 2007; Malavieille 2010; Smit et al. 2010), décollements in a sedimentary sequence or basement-cover interface (e.g. Konstantinovskaia \& Malavieille 2011), rheological evolution of the crust due to P-T changes through time (Carry et al. 2009; Gueydan et al. 2009), or structures and fabrics inherited from an earlier tectonic history (Sutton \& Watson 1986; Holdsworth et al. 1997; Butler et al. 2006, 2008; Bonnet et al. 2007, 2008). Among the large number of previous experimental studies of thrust wedges involving multiple décollements, only a few have suggested that faults development and evolution of structures could be cyclical under specific deformation conditions (e.g. Mulugeta \& Koyi 1992; Gutscher et al. 1998a; Malavieille 2010). 
102 Analog models allow to investigate the importance of surface processes (i.e. erosion 103 and sedimentation) and their influence on the dynamics of accretionary wedges (e.g.

104 Baby et al. 1995; Larroque et al. 1995; Storti \& McClay 1995; Mugnier et al. 1997;

105 McClay et al. 1999; Persson \& Sokoutis 2002; McClay et al. 2004; McClay \&

106 Whitehouse 2004; Konstantinovskaia \& Malavieille 2005, 2011; Graveleau \&

107 Dominguez 2008; Cruz et al. 2008, 2010; Malavieille 2010; Smit et al. 2010). Folding

108 represents another aspect of deformation processes investigated using analog

109 experiments but, although studied at different scales through different experimental

110 setups (e.g. Abbassi \& Mancktelow 1990; Grujic \& Mancktelow 1995; Tikof \&

111 Peterson 1998; Bazalgette \& Petit 2007; Noble \& Dixon 2011), fold development

112 have rarely been investigated at the scale of a whole accretionary wedge.

113

114 This study address five major questions: 1) how do décollements influence

115 deformation partitioning within thrust wedges, and their long term evolution, 2) which

116 mechanisms govern the development of large scale overturned folds commonly

117 preserved in mountain belt forelands as synformal fold-nappes klippen, 3) what

118 controls the growth of large scale antiformal structures that develop concomitantly in

119 the hinterland, 4) what are the interactions between relatively strong plastic layers

120 versus weak décollements, and 5) what is the impact of surface processes on all these

121 mechanisms? We present results of an analog modeling approach that takes into

122 account large amounts of shortening of mechanically heterogeneous, multilayered

123 materials and simultaneous surface erosion. Our first goal is to analyze the role of

124 strain partitioning in relation with material transfer by erosion. Then, we study the

125 impact of thin plastic layers interlayered in the incoming material on folding

126 mechanisms and on its evolution at the scale of a fold and thrust wedge. The main 
experimental results are discussed and compared to large-scale tectonic structures

128 from several mountain belts to better interpret their geometry and kinematic 129 evolution.

\section{Experimental set up and procedure}

132 The experimental set-up simulates the basic geometry and the main mechanisms of a

133 subduction zone where lower plate crustal materials sink beneath an upper plate. This

134 domain of the upper-plate located above the subduction interface corresponds in the

135 experiments to a deformable proto-forewedge equivalent to the units of the orogen

136 already accreted, deformed and structured following subduction. All experiments are

137 performed under normal gravity field in a classical sandbox (see Malavieille 1984 and

138 Konstantinovskaia \& Malavieille 2005, 2011), adapted to allow large shortening (over

$139200 \mathrm{~cm}$ ) and presenting a flexure of the basal plate taking into account the curvature

140 of a subducting plate.

141 The sandbox (Fig. 2) is $10 \mathrm{~cm}$ wide and $300 \mathrm{~cm}$ long, with a vertical rigid buttress. At

142 the base a thin plastic strip (dacron cloth) exits from the device through a thin slot

143 located at the base of the buttress. It is pulled by a computer controlled step by step

144 electric motor. Analog materials materializing the upper crust rocks of the lower plate

145 are deposited onto the plastic strip and are dragged toward the backstop. As they

146 cannot exit from the device, they are accreted against the upper-plate backstop. A thin

147 layer of sand is glued on the upper surface of the plastic strip, leading to a very rough

148 surface. It creates a high basal friction $\left(\mu_{\mathrm{b}} \approx 0.5\right)$ between the basal strip and the

149 analogue material of the models. According to the critical wedge theory (Davis et al.

150 1983; Dahlen et al. 1984; Dahlen 1984), the strength of the basal décollement 
151 influences the dipping of the main thrusts and backthrusts and the surface slope angle

152 of a wedge that satisfies the yield conditions.

154 Three different materials are used in the models. 1) Aeolian sand, with a density of

$1551690 \mathrm{~kg} / \mathrm{m} 3$, well rounded grains, less than $300 \mu \mathrm{m}$ in size, coefficient of internal

156 friction $\left(\mu_{0}\right)$ is 0.57 and the cohesion (C) is $100-150 \mathrm{~Pa}$. It composes the upper plate

157 protowedge and a large part of lower plate layers. 2) Glass microbeads poured in the

158 sandcake are used to model weak layers (décollements). Diameter is $100 / 200 \mu \mathrm{m}$, and

159 the perfect roundness of the grains leads a smaller coefficient of internal friction $\left(\mu_{0}=\right.$

160 0.44) and a negligible cohesion. 3) Plasticine is used to simulate folding because it

161 presents a plastic behavior. It is composed by mineral oils, waxes and a solid filler

162 made of fine powder $(15 \mu \mathrm{m})$. It does not contain water, does not dry, and can be

163 reused. The Plasticine is melted in an oven (softening point between 39 and $42^{\circ} \mathrm{C}$ ) and

164 poured in a $200 \times 9.8 \mathrm{~cm}$ mold. After cooling, $1 \mathrm{~mm}$ thin layers are sliced and then

165 included in the multilayered model. To observe the final deformation of the plastic

166 layer at the end of experiment, we have carefully cleaned the sand around the fold

167 limbs. Practically, in the experimental procedure, when a plasticine layer is emplaced

168 in the sand cake, the width of the thin plasticine sheet is slightly lower than the space

169 between the two glass sidewalls to avoid parasitic effects of lateral friction along the

170 glass. So, less than $1 \mathrm{~mm}$ of sand separates the plastic layer from the sidewall. As a

171 consequence, what we can observe directly through the glass sidewall is not the

172 plasticine layer itself, but the thin coloured sand marker which outlines its 173 deformation. 
176 Aeolian sand and glass microbeads are commonly used in physical modeling studies

177 as analogue of upper crustal rocks with a brittle behavior. The scaling factor between

178 their mechanical properties and those of the natural prototype is $10^{5}$ (Krantz 1991;

179 Schellart 2000; Lohrman et al. 2003). The same $10^{5}$ scaling factor is therefore used

180 for model dimensions $(1 \mathrm{~cm}=1 \mathrm{~km})$, in order to satisfy the fundamental scaling

181 theory for analogue modelling (Hubbert 1937, 1951; Horsfield 1977; Ramberg 1981;

182 Davy \& Cobbold 1991; Graveleau et al. 2011). Plasticine is a non-Newtonian fluid

183 characterized by strain rate-dependant plastic yielding and strain hardening. At

184 constant temperature, the constitutive flow law for plasticine is given by $\dot{\mathrm{E}}=C \sigma^{n}$,

185 where $\dot{\mathrm{E}}$ is the strain rate, $\mathrm{C}$ is a material constant, $n$ is a stress exponent, and $\sigma$ is the 186 differential stress (McClay 1976; Ranalli 1995). The apparent dynamic viscosity $(\eta)$

187 of plasticine is given by one half the ratio between the differential stress and the strain 188 rate: $\eta=\sigma /(2 \dot{\mathrm{E}})$.

189 Considering that experiments were carried at constant room temperature $(\mathrm{T} \sim 22$ -

$19025^{\circ} \mathrm{C}$ ) and that the strain rate of the plasticine layer during deformation is constant

191 and very low $\left(\dot{\mathrm{E}} \approx 1 \times 10^{-3} \mathrm{~s}^{-1}\right)$ then $\eta \approx 4 \times 10^{7} \mathrm{~Pa}$ s. This value of viscosity was

192 determined by mechanical experiments on plasticines (Schöpfer \& Zulauf 2002;

193 Zulauf \& Zulauf 2004) whose composition is similar to the plasticine used in our

194 analogue models.

195 The yield strength of a plasticine layer with millimetric thickness is roughly 196 equivalent to the compressional strength of a sand layer with centimetric thickness.

197 Thus, the strength contrast between plasticine layers and granular layers (sand or glass

198 microbeads) in our models is roughly equivalent to the strength contrast between

199 ductile yet strong rock layers (such as limestone) and weak rock layers (such as 
200 siltstones or shale). This strength contrast is typical of sedimentary sequences

201 observed in foreland and intra-mountainous basins in orogenic wedges.

203 Thirteen experiments have been run (Table 1). Among them, seven are chosen as 204 representative to describe the main results of our study. Erosion has been applied to 205 most of them, following the procedure described here below. First, an initial 206 shortening without erosion is applied to the models, allowing the development of a 207 wedge shaped topographic relief. This first step of wedge growth could be considered 208 as the analogue of wedge development in a poorly erosional submarine setting. Then, 209 erosion is applied step by step, each $2 \mathrm{~cm}$ of convergence (see digital screen in 210 experiment pictures for shortening values), simulating a climate-dependent erosion in 211 a subaerial wedge setting and keeping a constant evolution of the wedge topography.

212 It is performed by scraping off all the material rising above an imposed erosion 213 surface and then removing it with a vacuum cleaner. The slope of this erosion surface 214 can be variable or fixed and predetermined. In the former case the slope of the erosion 215 surface is adjusted step by step, in order to follow the "instantaneous" average slope 216 of the wedge, just smoothing in this way the small scale irregularities of the 217 topographic profile without altering its average slope. In the latter case an average 218 tilted erosion profile dipping from 3 to $10^{\circ}$ toward the foreland is maintained 219 (Konstantinovskaia \& Malavieille 2005, 2011; Bonnet et al. 2007, 2008). This slope 220 corresponds to the critical taper slope of a dry sand wedge (Davis et al. 1983). In this 221 case, local erosion rates are directly controlled by the activity of thrusts. Even if the 222 role of sedimentation has not specifically been taken into account in this study, small 223 piggy back basins that develop during wedge growth have been filled while 224 performing erosion to avoid unrealistic foreland topographies. 


\section{Experimental results}

227 Our new set of experiments complements previous modeling works on orogenic 228 processes carried out at the Geosciences Laboratory in Montpellier, which outline the 229 impact of coupling between surface and tectonic processes and the important role of 230 décollement levels during deformation (see, Malavieille et al. 1993; Larroque et al. 231 1995; Konstantinovskaia \& Malavieille 2005, 2011; Bonnet et al. 2007, 2008; 232 Malavieille 2010). Décollement layers favor the mechanical decoupling of stratified 233 material of the subducting plate and consequently, induce deformation partitioning. 234 While upper units are accreted at the toe of the wedge during propagation of the 235 deformation front (frontal accretion), lower units are underthrusted below the main 236 décollement fault and accreted at the base of the wedge by duplexing and 237 underplating (i.e. basal accretion). This partition between vertical and horizontal 238 accretion has a major impact on the organization of tectonic structures, deformation 239 and exhumation of deep units (e.g. Gutscher et al. 1998; Bonini 2001, 2003; Adam et 240 al. 2002; Kukowski et al. 2002; Konstantinovskaia \& Malavieille 2005, 2011; Bonnet 241 et al. 2007, 2008; Hoth et al. 2006, 2007, 2008; Malavieille 2010).

244 A microbeads layer deposited on the top surface of the lower plate (experiment 1, Fig. 245 3a) favors underthrusting of the tectonic units below the protowedge in the first steps 246 of experiments. During shortening, the wedge grows mostly in sequence by frontal 247 accretion and shows the typical structure of a simple sand wedge with no décollement 248 in the incoming sequence. We recognize typical structures of high basal friction 249 wedges built up by underthrusting of long tectonic units (e.g. Malavieille et al. 1992; 
251 \& Agrawal 2002; Kukowski et al. 2002; Konstantinovskaia \& Malavieille 2005;

252 Graveleau et al. 2012). In some cases, when the deformation front advances toward 253 the foreland through the nucleation of a new thrust, the previous frontal thrust remains 254 active until the end of the experiment. Internal deformation of individual foreward 255 vergent thrust units is accommodated by small backthrusts and only few large 256 backthrusts propagate through the whole wedge.

A microbeads layer positioned at $\sim 1 / 3$ of the total lower plate thickness favors remarkable strain partitioning (experiment 4, Fig. 3b). Materials of the upper portion 260 of the subducting plate are deformed by frontal accretion, leading to the development 261 of a typical low basal friction thrust wedge. Given the reduced thickness of the materials deformed by frontal accretion and the reduced basal friction, both the wedge taper angle (Fig. 3b) and the spacing between new thrust faults, are smaller than in experiment 1. Materials of the lower portion of the subducting plate are deformed by underplating and basal accretion (Fig. 3b). As already described in previous papers (e.g. Mulugeta \& Koyi 1992; Gutscher 1996, 1998a), underplating is not a steadystate process. More in detail, it can be noted that the evolution of the duplex structure is characterized by the activity of: i) large-offset faults (continuous lines in Fig. $3 b$

269 and 3c) allowing the accretion of a new unit at the base of the wedge; ii) small-offset 270 faults (dotted lines in Fig. 3b and 3c), allowing the accommodation of the internal 271 deformation of individual underplated units (Adam et al. 2002; Kukovski et al. 2002;

272 Hoth et al. 2008). The large shortening (of the experiments presented in this paper) 273 also allowed a second type of cyclicity to be observed at the whole-wedge scale.

274 When the first antiformal stack of underplated units reaches a critical size, it becomes 
inactive and the locus of underplating shifts to a more external position (e.g. toward

276 the foreland) where a second antiformal stack starts developing. The first underplating

277 domain is thus passively accreted and becomes part of the wedge upper-plate. Such a

278 mechanism of accretion repeats itself cyclically during the long-term evolution of a

279 wedge.

280 Growth of the antiformal stacks leads to some localized uplift of the overlying portion

281 of the wedge as manifested by the shape of the topographic profile, which shows two

282 evident bumps corresponding with the deep duplexes. By contrast the topographic

283 profile is quite regular in wedges lacking strain partitioning (Fig. 3a and 3b).

285 A microbeads layer located at shallow depth in the sandcake has a slight influence on 286 active deformation, without leading to efficient strain partitioning (experiment 6, Fig.

287 3d). Only second order small thrust units develop along the weak layer, involving the 288 upper portion of the subducting plate. Such small thrusts are regularly alternated with 289 major thrusts involving the whole subducting plate, and can therefore be considered 290 local splays of the main thrusts. The overall architecture of the wedge is that of a 291 classical high basal friction wedge, similar to the one obtained without microbeads 292 layer (Fig. 3d).

\section{Influence of a plastic layer on folding}

295 In experiment 10 (Fig. 4a) the introduction of a plastic layer in the subducting plate 296 drastically changes the tectonic style and kinematic evolution of the wedge, and leads 297 to folding processes at the scale of a whole accretionary wedge. The main 298 mechanisms of folds development in the experiment with no erosion are described 299 Fig. 5. Development of folds begins by buckling of the plastic layer, which is 
accommodated by a pop up structure in the overlying "brittle" sand layer. The

301 wavelength of buckling and the folding mechanism are controlled by the strength

302 contrast between the relatively strong yet ductile plasticine layer and weaker sand

303 layers (see previous section). Soon afterwards, the folding amplitude increases, folds

304 become asymmetric and overturned, controlled by progressive shearing deformation

305 induced by the growth of the prism. Shearing is partly responsible for the 306 development of the long inverted limbs, but the plastic layer is never disrupted or 307 stretched enough to be cut, thus allowing unrolling of the synclinal hinge. Fold 308 growth proceeds by continuous unrolling of the synclinal hinge which causes existing 309 nearby thrusts to become inactive, while new ones form. Then, the inactive faults are 310 passively transported along the inverted fold limb, although some can be reactivated 311 by out-of-sequence thrusting.

\section{Impact of surface erosion}

314 The effect of surface erosion is tested on wedges characterized by different tectonic 315 styles. In experiment 6, a simple high friction thrust wedge showing no strain 316 partitioning or folding is submitted to erosion. It is comparable to experiment 1 , 317 except the latter did not include erosion. Figure $3 \mathrm{~d}$ outlines the similar tectonic styles 318 of both models, and similar taper angle of their pro-wedges.

320 Experiment 5 (Fig. 3c) shows the effects of erosion on a wedge characterized by 321 strong strain partitioning, to be compared with experiment 4, which has the same 322 initial setup but no erosion. In both models permanent underplating leads to the 323 development of a large antiformal stack formed by basal accretion of duplex units. It 324 induces uprising of internal domain and subsequent localized surface uplift. In model 
3255 , however, surface uplift enhances localized surface erosion, which in return favors

326 further uplift and localization of underplating. As shown in figure $3 \mathrm{c}$ the final product

327 of this process is the exhumation of underplated units in localized areas.

329 In experiment 11 (Fig. 4b) a model involving a plastic layer is submitted to erosion in 330 order to investigate the impact of surface processes on the dynamics of folding. 331 Compared to experiment 10, which has the same initial setup, experiment 11 shows 332 several differences in the general tectonic style. Despite erosion of anticlinal fold 333 hinges, shear deformation increases the length of the inverted sequence, which is 334 associated with the unrolling, and migration of the synclinal fold hinge. Frontal 335 accretion spreads but the amount of shortening accommodated through each folded 336 tectonic unit is higher. The material removed by erosion delays the growth of the 337 wedge and thus its ability to propagate the deformation forward through new tectonic 338 units. Although the anticline hinge is being removed by erosion, unrolling of the 339 syncline hinge continues suggesting that the inverted limb is not submitted to traction.

340 The diffuse shear deformation involved in the core of folds due to asymmetric 341 shortening could be responsible for the forward migration (relative to the undeformed 342 foreland) of the synclinal hinge.

343 To summarize the main differences, we note that each unit is more intensely deformed

344 and that the length of fold limbs is greater in the experiment with erosion. In addition, 345 for an equivalent amount of shortening, less tectonic units were formed.

Brittle/ductile multilayer and underplating

348 In experiments 10 and 11, large-scale isoclinals folds developed with an average final 349 overturning of the limbs ranging between $30^{\circ}$ and $50^{\circ}$. These modeling results cannot 
explain what is commonly observed in many natural mountain forelands where large

351 scale inverted fold limbs rest close to horizontal over kilometers. Thus, important

352 questions remain: what mechanism is responsible for the huge overturning observed?

353 And, does this mechanism occur during folds development or by rigid rotation due to

354 late tilting? In order to answer these questions, we have taken into account the

355 insights from the experiments involving basal accretion. As previously shown,

356 décollement layers play a key role during deformation and interactions with surface

357 processes, that seems major too for the development of folding during the growth of

358 fold and thrust belts.

359 In experiment 13 (Fig. 4c) we tested the impact of heterogeneous layering involving

360 décollements, brittle and plastic behaviors (very common in foreland belts). The

361 model combines strain partitioning, folding and surface erosion. A $5 \mathrm{~mm}$ thick layer

362 of sand is placed between a $1 \mathrm{~mm}$ thick plasticine sheet and the $3 \mathrm{~mm}$ thick weak

363 layer of glass microbeads. The complete evolution of the experiment is described in

364 the figure 6 . Erosion begins after $15 \mathrm{~cm}$ of shortening and the wedge slope is 365 sustained at about $3^{\circ}$ during shortening $(60 \%$ at the end of the experiment). During 366 convergence, fold hinges are rapidly eroded, while active thrusting occurs in the core

367 of folds. Six folded tectonic units were obtained and a large domain of deeply 368 accreted units is exhumed behind the prism. Note that we also observed the cyclical 369 behavior of underplating as described previously.

370 The structures located above the décollement layer are passively deformed and 371 uplifted due to basal accretion, tilting the back part of folded tectonic units. These 372 deep accretionary processes are responsible for the important overturning and rotation 373 of the flanks of folded structures. During continuous shortening, the kinematics of 374 deformation reflects the complex interaction between wedge mechanics and erosion. 
375 At the final stage most of the folded units from the backpart of the wedge have been 376 removed by erosion. Finally, three different tectonic domains characterized by 377 specific deformation features are juxtaposed. From the frontal part of the wedge to the 378 backstop respectively, we have (Fig. 6): a frontal imbricate of thrust and fold sheets; a

379 synformal klippe of folded units previously accreted to the front and progressively 380 deformed; and, an antiformal stack of underplated thrust units refolding the upper 381 décollement layer.

\section{Discussion and case studies}

384 Results of this series of experiments give some insights for the interpretation of 385 several debated features of the forewedge domain of mountain belts formed in 386 continental subduction settings. Chosen case studies are discussed in the light of our 387 experimental results. The last model, which contains the main features described in 388 previous sections, is used to illustrate the general mechanisms explaining the 389 relationships between the main tectonic units of natural orogenic wedges (Fig. 7).

\section{Examples from the Variscan Belt}

392 The Variscan orogen developed during the Gondwana-Laurasia collision from 393 Devonian to middle Carboniferous times (e.g. Matte 2007). The Montagne Noire in 394 southern French Massif Central and the Galicia Mountains in northwest Spain 395 represent segments of this orogen characterized by a foreland fold and thrust belt 396 domain associated with a syntectonic foreland basin (e.g. Arthaud 1970; Matte 1968; 397 Pérez-Estàun et al. 1991; Simancas et al. in press). Low-grade tectonic units mainly 398 composed by sedimentary rocks of the Paleozoic cover (schists, limestones and 399 quartzites of Cambrian to Carboniferous ages) are intensely folded and juxtaposed 
400 with antiformal stacks of Proterozoic to Cambrian metamorphic basement rock units 401 largely exhumed in the hinterland. The Montagne Noire which forms the 402 southernmost part of the Variscan French Massif Central (Fig. 8) is generally 403 subdivided into three tectonostratigraphic units (e.g. Gèze 1949; Arthaud 1970). (1) A

404 Northern Flank upper-plate unit with a southward tectonic vergence, consists of 405 folded and faulted low-grade lower Paleozoic metasedimentary rocks. (2) An Axial 406 Zone lower-plate unit, is formed by an antiformal structure of crystalline rocks 407 (gneiss, migmatite, and micaschist) of Proterozoic to Ordovician age. This 408 metamorphic domain composed by high grade rocks has been variously interpreted in 409 terms of : diapirism (e.g. Gèze 1949; Beaud 1985 ; Charles et al. 2009), contractional 410 tectonics (Arthaud et al. 1966; Mattauer et al. 1996; Aerden \& Malavieille, 1999; 411 Soula et al. 2001; Matte, 2007; Malavieille 2010), emplacement in a crustal scale 412 strike-slip setting (e.g. Nicolas et al. 1977; Franke et al. 2011), or as extensional 413 metamorphic core complex (e.g. Echtler \& Malavieille, 1990; Van den Driessche \& 414 Brun 1992). In fact, most authors agree on the geological evidences for a 415 contractional history followed (or assisted) by gravity induced extensional processes 416 favoring exhumation, detachment formation and diapirism in the evolutionary stages 417 of the orogen. (3) A Southern Flank, well known in the literature for the kilometer418 scale recumbent fold nappes, is composed by very low-grade Paleozoic sedimentary 419 sequences. The south verging nappes stack is intimately associated with syntectonic 420 Visean flysch sediments deposited in a foreland basin setting, in a shallow marine 421 environment. The upper-plate nappes are separated from high-grade lower-plate 422 basement units by major fault zones that record a complex pattern of deformation 423 (e.g. Echtler \& Malavieille 1990; Aerden \& Malavieille 1999). Figure 8 shows an 424 interpreted cross section of The Montagne Noire (Malavieille 2010). 
425 Similar key structures of the Galicia Mountain Belt are outlined on the cross-section

426 of figure 9, modified from Pérez-Estàun et al. (1991). Proterozoic metamorphic units

427 outcrop in the internal domain while a domain of large scale recumbent folds made of

428 Cambrian quartzite/limestone characterizes external foreland units. These kilometric

429 scale folds present horizontal or overtilted limbs (Matte 1968; Pérez-Estàun et al.

430 1991). Note that in this segment of the Variscan belt, a cyclical basal accretion may

431 have occurred at large scale, as two antiformal stack structures formed during wedge

432 growth.

434 Comparing wedges architecture and analog models, we can outline geometrical and 435 kinematic similarities. As observed in models involving décollements and 436 brittle/plastic behavior, there is a good analogy between the geometric configuration 437 of the folded superficial domain and the underlying deeper structures. Where 438 underplating develops, the folded units located above the décollement layer are 439 strongly tilted by subsequent uplift in the antiformal stack domain. This can be 440 compared to the fold-nappes structures of the Galicia belt or Montagne Noire. In the 441 parts of the orogenic wedge located far from the locus of basal accretion, large scale 442 folds are simply overturned. During the growth of the Montagne Noire, syntectonic 443 flysches (Visean) are deposited at the toe of the wedge due to erosion of developing 444 fold nappes (Southern flank). At the same time, basal accretion is active during the 445 growth of the prism involving underthrusting of sliced Proterozoic basement and 446 subsequent uplift at the back of the overturned fold domain. Already deformed Upper 447 Paleozoic units are overtilted by progressive uplift. The décollement layer allowing 448 strain partitioning between shallow and deep parts of the wedge is located along the 
main inherited discontinuity, between the crystalline basement and the Paleozoic cover.

451 Figure 6 highlights the major effect of erosion on deformation processes. During 452 wedge growth, due to combined basal accretion, surface uplift and erosion, 453 continuous folding affects tectonic units of the upper-plate that remain at the same 454 structural level in the upper crust whereas large domains of deep metamorphic units 455 of the lower-plate are exhumed. Thus, the deformation mechanisms highlighted in our 456 study may explain how the large scale recumbent fold-nappes with inverted limbs of $45710 \mathrm{~km}$ develop, and why they suffered only slight or no metamorphism.

\section{Northern Apennines}

460 The Apennines are a fold and thrust mountain chain constituting the backbone of the

461 Italian peninsula. Figure 10a outlines some aspects of the northernmost portion of this 462 chain (e.g. Molli 2008). The internal zone is characterized by a metamorphic core 463 where two main exhumed tectonostratigraphic units outcrop. The lowermost is the 464 Apuane unit, a low grade metamorphic unit showing greenschist assemblages 465 (deepest estimated burial: $\sim 20 \mathrm{~km}$ ). On the western side of the core, the Apuane unit 466 is overlaid by the Massa unit, an HP greenschist facies metamorphic unit with higher 467 grade $\mathrm{P} / \mathrm{T}$ peak conditions (estimated deepest burial: $\sim 25 / 30 \mathrm{~km}$ ). The whole 468 metamorphic core is overlaid by the Tuscan Nappe, an anchimetamorphic unit with a 469 deepest estimated burial of $\sim 7 \mathrm{~km}$, which in turn is overlaid by Subligurian and 470 Ligurian non-metamorphic units and by the Epiligurian basin (e.g. Fellin et al. 2007 471 and references therein). In a central portion, east of the Alpi Apuane, the chain is 472 characterized by a recumbent fold domain (Fig. 10b) where the Tuscan Nappe is 473 folded in a kilometric-scale recumbent structure (the Val di Lima fold), with an 
474 outcropping kilometers long inverted limb. This recumbent fold shows minor 475 structures related with superimposed deformations (Baldacci et al. 1992; Fazzuoli et 476 al. 1998) with development of the long inverted limb by progressive hinge migration 477 (Botti et al. 2010).

478 The overall geometrical configuration of the analyzed segment of the Apennines (Fig. 479 10) can be interpreted in the light of our models. The combined action of basal 480 accretion and underplating of tectonic units produced the growth of a syn481 metamorphic antiformal stack (Molli \& Vaselli 2006) responsible of strong uplift and 482 exhumation by submarine (in the early stages) and later surface erosion (Molli et al. 483 2002; Fellin et al. 2007). Erosion-processes were associated with tectonic thinning by 484 normal-slip reactivation of the basal thrust of the unmetamorphic units at the hanging 485 wall and the metamorphic core at the footwall (Carmignani \& Kligfield 1990; Molli et 486 al. 2002; Fellin et al. 2007; Molli 2008). Moreover, the growth of the antiformal stack 487 may have induced progressive tilting of the basal detachment and the formation of 488 recumbent geometry of the folded Tuscan unit in the Lima Valley (Fig.10a,b).

489 Indeed, the locus of basal accretion and the folded domain are close enough to 490 presume the influence of the underlying deep structures on the passive rotation of the 491 fold limbs. Model results can give some more hints on the processes that may have 492 influenced the geological evolution of the metamorphic core, suggesting that two 493 successive episodes of underplating, could have been responsible for the syn494 contractional juxtaposition of the Massa unit above the Apuan unit.

Open questions in other mountain belts

497 Mechanisms responsible for deformation structures and exhumation processes 498 developed in the Himalayas are presently widely discussed through two main kind of 
500 et al. 2004; and wedge extrusion in a thrust system, e.g. Burchfiel \& Royden 1985;

501 England \& Molnar 1993; Guillot \& Allemand 2002, Webb et al. 2007, Kali et al. 502 2010). Our study outline simple mechanisms that seem to be consistent with the 503 observed large-scale geological structures (antiformal stacks, synformal klippen of 504 fold and thrust units), in agreement with the second orogenic wedge model.

\section{Conclusions}

Interaction between climate controlled surface processes including erosion,

508 sedimentation and deformation processes plays a key role in the structural evolution, 509 kinematics and exhumation of rocks in orogenic wedges. During continental 510 subduction, the role of the rheologic layering of the crust can be major as it 511 determines the partitioning of deformation in a growing orogenic wedge into domains 512 undergoing horizontal and vertical accretion. Partitioning is first controlled by 513 tectonic processes, but material transfer induced by surface processes exerts a strong 514 feed-back on wedge dynamics. Insights from analog models applied to natural cases 515 allow us to emphasize several first order interaction mechanisms that result from this 516 coupling. Experiments show that strain partitioning is not systematic but depends on 517 the position of weak layers in the layered incoming sequence. They show a cyclical 518 behavior of basal accretion, leading to episodic underplating of tectonic units, which 519 has a strong impact on the vertical component of displacement of rock material. In 520 turn, it changes surface slopes favoring erosion in domains of strong surface uplift. In 521 addition, our experiments offer an explanation for the enigmatic domains of non 522 metamorphic large scale fold nappes units observed in the foreland of many orogenic 523 wedges. To a first order, the dynamics of folding involves rolling of a synclinal hinge 
524 and develop exclusively overturned fold types. This mechanism was observed, in 525 particular, for multilayered models constituted of both strong yet ductile layers and 526 comparatively weaker granular layers.

527 The influence of the deep wedge dynamics, such as the growth of basal duplexes, 528 causes further rotation of fold structures, leading to the horizontalization of fold 529 limbs, while erosion processes keep the folded units in a superficial low-grade 530 metamorphic domain. Natural wedges (e.g. Galicia, Montagne Noire and Northern 531 Apennines) present close similarities to the experiments described herein, both in 532 terms of architecture and orogenic dynamics. Other orogenic wedges exposing similar 533 structures such as exhumed antiformal metamorphic domes juxtaposed with domains 534 of largely folded upper-crustal rock sequences need to be revisited in the light of the 535 general mechanisms here outlined.

536 Future work should concentrate on multilayered models with different rheological 537 contrasts (e.g. weak ductile layers and strong brittle layers) to determine other 538 possible large-scale folding mechanisms in the shallow domains of orogenic wedges.

\section{Acknowledgements}

542 Our modeling work has benefitted from the technical assistance of C. Romano. Many 543 thanks to Nina Kukowski who helped us improving an early version of the 544 manuscript. This study has been partly funded in the frame of the ACTS ANR project. 545 The contibution by Clemenzi has benefitted from an Erasmus Placement exchange 546 and funding between Pisa and Montpellier Universities. This paper benefitted from 547 constructive review by D.G.A.M. Aerden and an anonymous reviewer. 


\section{References}

551 Abbassi, M. R. \& Mancktelow, N. S. 1990. The effect of initial perturbation shape 552 and symmetry on fold development. Journal of Structural Geology, 12, 273-282.

554 Adam, J., Lohrmann, J., Hoth, S., Kukowski, N. \& Oncken, O. 2002. Strain 555 variation and partitioning in thrust wedges: high-resolution data from scaled sandbox 556 experiments by 2D-3D PIV analysis. Bollettino di Geofisica Teorica ed Applicata, $557 \quad 42,123-125$.

558

559 Aerden, D. G. A. M. \& Malavieille, J. 1999. Origin of a large-scale fold nappe in 560 the Montagne Noire, Variscan belt, France. Journal of Structural Geology, 21, 13215611333.

Aerden, D. G. A. M., Bell, T. H., Puga, E., Sayab, M., Lozano, J. A. \& Diaz De 564 FEDERICO, A. 2013. Multi-stage mountain building vs. relative plate motions in the 565 Betic Cordillera deduced from integrated microstructural and petrological analysis of 566 porphyroblast inclusion trails. Tectonophysics, 587, 188-206

568 Agarwal, K. K. \& Agrawal, G. K. 2002. Analogue sandbox models of thrust 569 wedges with variable basal frictions. Gondwana Research, 5, 641-647.

571 ARTHAUD, F. 1970. Etude tectonique et microtectonique comparée de deux domaines

572 Hercyniens : les nappes de la Montage Noire (France) et l'anticlinorum de l'Iglesiente 573 (Sardaigne). Publications de l'université des Sciences et Techniques du Languedoc, 
Montpellier. Série Géologie Structurale, 1.

575

576 Arthaud, F., Mattauer, M. \& Proust, F, 1966. La structure et la microtectonique

577 des nappes hercyniennes de la Montagne Noire. Colloque "Étages Tectoniques",

578 Neuchâtel, 231-247.

579

580 Avouac, J. P. 2003. Mountain Building, Erosion, and the Seismic Cycle in the Nepal

581 Himalaya. In: Advances in Geophysics, Elsevier, 46, 1-80.

582

583 Baby, P., Colletta, B. \& ZubietA, D. 1995. Etude géométrique et expérimentale 584 d'un bassin transporté: exemple du synclinorium de l'Alto Beni (Andes centrales). 585 Bulletin de la Société Géologique de France, 166, 797-811.

Baldacci, F., Carmignani, L., Fantozzi, P., Meccheri, M. \& Plesi, G. 1992.

588 Lineamenti stratigrafico-strutturali lungo la trasversale Alpi Apuane - Appennino 589 reggiano-modenese. Studi Geol. Camerti, Vol. Spec., 31-49.

590

591 Bazalgette, L. \& Petit, J. P. 2007. Fold amplification and style transition involving 592 fractured dip-domain boundaries: buckling experiments in brittle paraffin wax 593 multilayers and comparison with natural examples. In: LONERGAN, L., JOLLY, R.J.H., 594 Rawnsley, K. \& Sanderson, D. J. (eds) Fractured Reservoirs. Geological Society, 595 London, Special Publications, 270, 157-169.

597 BEAud, F. 1985. Etude structurale de la Zone Axiale orientale de la Montagne Noire 598 (Sud du Massif Central Français). Détermination des mécanismes de déformation. 
599 Relation avec les nappes du Versant Sud. Thèse 3ème cycle, Université des Sciences 600 et Techniques du Languedoc, Montpellier, 191 p.

601

602 Beaumont, C., Jamieson, R. A., Nguyen M. H. \& Lee, B. 2001. Himalayan tectonics 603 explained by extrusion of a low-viscosity crustal channel coupled to focused surface 604 denudation, Nature, 414, 738-742, doi:10.1038/414738a

605

606 Bell, T. H. \& Johnson, S. E. 1989. Porphyroblast inclusion trails: the key to 607 orogenesis. Journal of Metamorphic Geology. 7, 279-310, doi:10.1111/j.1525$608 \quad$ 1314.1989.tb00598.x

609

610 BeLl, T. H. \& SAPKOTA, J. 2012. Episodic gravitational collapse and migration of the 611 mountain chain during orogenic roll-on in the Himalayas. Journal of Metamorphic 612 Geology, 30, 651-666, doi: 10.1111/j.1525-1314.2012.00992.x

613

614 BonINI, M. 2001. Passive roof thrusting and forelandward fold propagation in scaled 615 brittleductile physical models of thrust wedges. Journal of Geophysical Research, 616 106(B2), 2291-2311.

617

618 BonINI, M. 2003. Detachment folding, fold amplification, and diapirism in thrust 619 wedge experiments. Tectonics, 22(6): 1065.

620

621 Bonnet, C., Malavieille, J. \& Mosar, J. 2007. Interactions between tectonics, 622 erosion, and sedimentation during the recent evolution of the Alpine orogen: 623 Analogue modeling insights. Tectonics, 26, TC6016, doi : 10.1029/2006TC002048. 
625 Bonnet, C., Malavieille, J. \& Mosar, J. 2008. Surface processes versus kinematics 626 of thrust belts: impact on rates of erosion, sedimentation, and exhumation - Insights 627 from analogue models. Bulletin de la Société Géologique de France, 179, 179-192.

628

629 Botti, F., Daniele, G., Baldacci, F. \& Molli, G. 2010. Note Illustrative della Carta 630 Geologica d'Italia alla scala 1: 50.000, Foglio 251 Porretta Terme. Servizio Geologico 631 d'Italia, Regione Emilia-Romagna.

632

633 Burchfiel, B. C. \& Royden, L. H., 1985. North-south extension within the 634 convergent Himalayan region, Geology, 13, 679-682

635

636 Burkhard, M. \& Sommaruga, A. 1998. Evolution of the western Swiss Molasse 637 basin: structural relations with the Alps and the Jura belt. In: MASCLE, A, 638 Puigdefabregas, C., Luterbacher, H.P. \& Fernandez, M. (eds) Cenozoic 639 Foreland Basins of Western Europe. Geological Society, London, Special 640 Publications, 134, 279-298.

641

642 Butler, R. W. H., Tavarnelli, E. \& Grasso, M. 2006. Structural inheritance in 643 mountain belts : An Alpine-Apennine perspective. Journal of Structural Geology, 28, 644 1893-1908.

645

646 Butler, R. W. H., Bond, C. E., Shipton, Z. K., Jones, R. R. \& Casey, M. 2008. 647 Fabric anisotropy controls faulting in the continental crust. Journal of the Geological 648 Society, London, 165, pp. 449-452. 
650 Carmignani, L. \& Kligfield, R. 1990. Crustal extension in the Northern Apennines:

651 the transition from compression to extension in the Alpi Apuane Core Complex. 652 Tectonics, 9, 1275-1303.

653

654 Carry, N., Gueydan, F., Brun, J. P. \& Marquer, D. 2009. Mechanical decoupling 655 of high-pressure crustal units during continental subduction. Earth and Planetary 656 Science Letters, 278, 13-25.

658 Charles, N., Faure, M., And Chen, Y. 2009. The Montagne Noire migmatitic dome 659 emplacement (French Massif Central): new insights from petrofabric and AMS 660 studies. Journal of Structural Geology, 31, 1423-1440, doi:10.1016/j.jsg.2009.08.007 661

662 Costa, E. \& Vendeville, B. E. 2002. Experimental insights on the geometry and 663 kinematics of fold-and-thrust belts above weak, viscous evaporitic décollement. 664 Journal of Structural Geology, 24, 1729-1739.

665

666 Cruz, L., Teyssier, T., Perg, L., Take, A. \& Fayon, A. 2008. Deformation, 667 exhumation, and topography of experimental doubly-vergent orogenic wedges 668 subjected to asymmetric erosion. Journal of Structural Geology, 30, 98-115.

669

670 Cruz, L., Malinski, J., Wilson, A., Take, W. A. \& Hilley, G. 2010. Erosional 671 control of the kinematics and geometry of fold- and- thrust belts imaged in a physical 672 and numerical sandbox. Journal of Geophysical Research, 115, B09404, 673 doi:10.1029/2010JB007472. 
675 DAhlen, F.A. 1984. Non cohesive critical coulomb wedges: an exact solution. 676 Journal of Geophysical Research, 89, 10125-10133.

678 Dahlen, F. A., SupPe, J. \& Davis, D. 1984. Mechanics of fold-and-thrust belts and 679 accretionary wedges: cohesive coulomb theory. Journal of Geophysical Research, 89, $680 \quad 10087-10101$.

681

682 Davis, D., Suppe, J. \& Dahlen, F. A. 1983. Mechanics of fold-and-thrust belts and 683 accretionary wedges. Journal of Geophysical Research, 88, 1153-1172.

684

685 DAvis, D. \& Engelder T. 1985. The role of salt in fold-and-thrust belts. 686 Tectonophysics, 119, 67-88

DAVy, P. \& CobBold, P. R. 1991. Experiments on shortening of a 4-layer model of 689 the continental lithosphere. Tectonophysics, 188, 1-25.

690

691 Echtler, H., \& Malavieille, J. 1990. Extensional tectonics, basement uplift and 692 Stephano- Permian collapse basin in a late Variscan metamorphic core complex 693 (Montagne Noire, southern Massif Central). Tectonophysics, 177, 125-138.

695 England, P., \& Molnar, P. 1993. Cause and effect among thrust and normal 696 faulting, anatectic melting and exhumation in the Himalaya. In: TreloAR, P. J., 697 Searle, M. P. (Eds.), Himalayan Tectonics. Geological Society, London, Special 698 Publications, 74, 401-411. 
700 Elliott, D., \& Johnson, M. R. W. 1980. Structural evolution in the northern part of

701 the Moine thrust belt, NW Scotland. Edinburgh Geological Society Transactions,

702 Earth Sciences, 71, 69-96.

703

704 Fazzuoli, M., Becarelli, S., Burchietti, G., Ferrini, G., Garzonio, C.A., 705 Mannori, G., Sani, F. \& Sguazzoni, G. 1998. Geologia del nucleo Mesozoico della 706 Val di Lima (Provincie di Pistoia e Lucca, Appennino settentrionale). Note illustrative 707 della carta geologica (Scala 1: 25.000). Bollettino della Società Geologica Italiana, $708 \quad 117,479-535$.

709

710 Fellin, M. G., Reiners, P. W., BrAndon, M. T., WÜThrich, E., BAlestrieri M. L. \& 711 MolLi, G. 2007. Thermochronologic evidence for the exhumational history of the 712 Alpi Apuane metamorphic core complex, northern Apennines, Italy. Tectonics, 26, 713 TC6015, doi:10.1029/2006TC002085

715 Fossen, H. 2010. Structural Geology, Cambridge University Press, 463 pp., ISBN-13 $978-0-521-51664-8$

718 Franke, W., Doublier, M. P., Klama, K., Potel, S. \& Wemmer, K. 2011. Hot 719 metamorphic core complex in a cold foreland. International Journal of Earth 720 Sciences, 100, 753-785, doi:10.1007/s00531-010-0512-7.

722 GÈzE, B. 1949. Etude géologique de la Montagne Noire et des Cévennes 723 méridionales. Mémoires de la société géologique de France, 62, 1-215. 
725 Graveleau, F. \& Dominguez, S. 2008. Analogue modelling of the interaction 726 between tectonics, erosion and sedimentation in foreland thrust belts. C.R. 727 Géoscience, 340, 324-333

729 Graveleau, F., Hurtrez, J.-E., Dominguez, S. \& Malavieille, J. 2011. A new 730 experimental material for modeling relief dynamics an interactions between tectonics 731 and surface processes. Tectonophysics, 513, 68-87.

Graveleau, F., Malavieille, J. \& Dominguez, S. 2012. Experimental modelling of 734 orogenic wedges: A review. Tectonophysics, 538, 1-66.

Grujic, D. \& MANCKTElow, N.S. 1995. Folds with axes parallel to the extension direction: an experimental study. Journal of Structural Geology, 17, 279-291

Gueydan, F., Le GARZIC, E. \& CARRY, N. 2009. P/T ratio in high-pressure rocks as a function of dip and velocity of continental subduction. Lithosphere, 1, 282-290.

742 Guillot, D., \& Allemand, P. 2002. Two dimensional thermal modelling of the early 743 tectonometamorphic evolution in central Himalaya, Journal of. Geodynamics, 34, 77744 98, doi:10.1016/S0264-3707(02)00016-9.

746 Gutscher, M. A., Kukowski, N., Malavieille, J. \& Lallemand, S. 1996. Cyclical 747 behavior of thrust wedges: Insights from high basal friction sandbox experiments. 748 Geology, 24, 135-138. 
750 Gutscher, M. A., Kukowski, N., Malavieille, J. \& Lallemand, S. 1998a.

751 Episodic Imbricate thrusting \& underthrusting; Analog experiments and Mechanical 752 Analysis applied to the Alaskan Accretionary Wedge. Journal of Geophysical 753 Research., 103, 10161-10176.

754

755 Gutscher, M. A., Kukowski, N., Malavieille, J. \& Lallemand, S. 1998b. 756 Material transfer in accretionary wedges from analysis of a systematic series of analog 757 experiments. Journal of Structural Geology, 20, 407-416.

758

759 HATChER JR, R. D. 1989. Tectonic synthesis of the U.S. Appalachians. In: HATCHER, 760 R.D., Thomas, W.A., AND VIELE, G.W. (eds), The Appalachian-Ouachita Orogen in 761 the United States : Boulder, Colorado. The Geology of North America, F-2, 511-535.

763 Holdsworth, R. E., Butler, C. A. \& Roberts, A. M. 1997. The recognition of 764 reactivation during continental deformation. Journal of the Geological Society, 765 London, 154, 73-78.

766

767 HorsfiElD, W. 1977. An experimental approach to basement-controlled faulting. 768 Geologie en Mijnbouw, 56, 363-370.

770 Hoth, S., AdAm, J., KuKowski, N. \& OnCKEN, O. 2006. Influence of erosion on the 771 kinematics of bivergent orgens. Results from scaled sandbox simulations. In: 772 Willett, S.D., Hovius, N., Brandon, M.T., Fisher, D.M. (eds), Tectonics, Climate, 773 and Landscape Evolution. The Geological Society of America, Boulder, Colorado, 
Hoth, S., Hoffmann-Rothe, A. \& Kukowski, N. 2007. Frontal accretion: an internal clock for bivergent wedge deformation and surface uplift. Journal of Geophysical Research, 112, B06408. doi:10.1029/2006JB004357.

780 Hoth, S., KuKowski, N. \& OnCKen, O. 2008. Distant effects in bivergent orogenic

781 belts - how retro-wedge erosion triggers resource formation in pro-foreland basins. 782 Earth and Planetary Science Letters, 273(1-2), 28-37.

784 HubBert, M. K. 1937. Theory of scale models as applied to the study of geologic 785 structures. Bulletin of the Geological Society of America, 48, 1459-1519.

HubBert, M. K. 1951. Mechanical basis for certain familiar geologic structures. Bulletin of the Geological Society of America, 62, 355-372.

791 channel flows: 2. Numerical models with implications for metamorphism in the 792 Himalayan-Tibetan orogen, Journal of Geophysical Research, 109, B06407, 793 doi:10.1029/2003JB002811.

795 Kali, K. E., Leloup, P. H., Arnaud, N., Maheo, G., Dunyi Liu, Boutonnet, E., 796 Van der Woerd, J., Xiaohan LiU, Jing LiU-Zeng, and Haibing Li 2010. 797 Exhumation history of the deepest central Himalayan rocks, Ama Drime range: Key 798 pressure-temperature-deformation-time constraints on orogenic models. Tectonics, 
800

801 Konstantinovskaia, E. \& Malavieille, J. 2005. Erosion and exhumation in 802 accretionary orogens: Experimental and geological approaches. Geochemistry, 803 Geophysics, Geosystems, 6, Q02006, doi:10.1029/2004GC000794, ISSN: 1525-2027 804

805 Konstantinovskaia, E. \& Malavieille, J. 2011. Thrust wedges with décollement 806 levels and syntectonic erosion: A view from analogue models. Tectonophysics, 502 807 336-350, 10.1016/j.tecto.2011.01.020.

808

809 Koyi, H. A. \& Vendeville, B. C. 2003. The effect of décollement dip on geometry 810 and kinematics of model accretionary wedges. Journal of Structural Geology, 25, $811 \quad 1445-1450$.

812

813 KRANTZ, R. W. 1991. Measurements of friction coefficients and cohesion for faulting 814 and fault reactivation in laboratory models using sand and sand mixtures. 815 Tectonophysics, 188, 203-207.

817 Kukowski, N., Lallemand, S., Malavieille, J., Gutscher, M.A. \& Reston T.J. 818 2002. Mechanical decoupling and basal duplex formation observed in sandbox 819 experiments with application to the Western Mediterranean Ridge accretionary 820 complex. Marine Geology, 186, 29-42

822 Lallemand, S., Schnurle, P. \& Malavieille, J. 1994. Coulomb theory applied to 823 accretionary and non-accretionary wedges - Possible causes for tectonic erosion 
and/or frontal accretion. Journal of Geophysical Research, 99(B6), 12033-12055.

825

Larroque, C., Calassou, S., Malavieille, J. \& Chanier, F. 1995. Experimental

827 modelling of forearc basin development during accretionary wedge growth. Basin 828 Research, 7(3), 255-268.

829

830 LiU, S. \& DiXON, M. 1990. Centrifuge modelling of thrust faulting: strain partitioning 831 and sequence of thrusting in duplex structures. Geological Society, London, Special 832 Publications. 54, 431-444.

833

834 LiU, H., McClay, K. \& Powell, D. 1992. Physical models of thrust wedges. In:

835 McClay K. (ed) Thrust Tectonics. Chapman and Hall, London, 71-81.

836

Lohrman, J., KukOwski, N., AdAm, J. \& OnCKen, O. 2003. The impact of analogue 838 material properties on the geometry, kinematics, and dynamics of convergent sand 839 wedges. Journal of Structural Geology, 25, 1691-1711.

840

841 Long, S., McQuarrie, N., Tobgay, T. \& Hawthorne, J. 2011. Quantifying internal 842 strain and deformation temperature in the eastern Himalaya, Bhutan: Implications for 843 the evolution of strain in thrust sheets. Journal of Structural Geology, 33, doi: $844 \quad 10.1016 /$ j.jsg.2010.12.011

845

846 MalavieILle, J. 1984. Modélisation expérimentale des chevauchements imbriqués: 847 Application aux chaînes de montagnes. Bulletin de la Société Géologique de France, $848 \quad 26,129-138$. 
850 Malavieille, J. 2010. Impact of erosion, sedimentation, and structural heritage on

851 the structure and kinematics of orogenic wedges: Analog models and case studies.

852 GSA Today, 20, doi: 10.1130/GSATG48A.1

853

854 Malavieille, J., Calassou, S., Lallemand, S. \& Larroque, C. 1992. Experimental 855 modeling of accretionary wedges. Série cours M037, Producted and realized by $856 \mathrm{SNEA}(\mathrm{P})$, France, $28 \mathrm{~min}$.

858 Malavieille, J., Larroque, C., Calassou, S. 1993. Modelisation experimentale des 859 relations tectonique/sedimentation entre bassin avant-arc et prisme d'accretion. 860 Comptes rendus de l'Académie des sciences, 316, 8, 1131-1137

861

862 Mandal, N., Chattophdhyay, A. \& Bose, S. 1997. Imbricate thrust spacing: 863 experimental and theoritical analyses. In: SENGUPTA, S. (ed) Evolution of Geologic 864 Structures in Micro to Macro-scale. Chapman \& Hall, London, 143-165. 865

866 MCClAy, K. 1976. The rheology of plasticine. Tectonophysics, 33, T7- T15.

868 McClay, K., Dooley, T. \& Whitehouse O. 1999. Analogue modelling of thin and 869 thick-skinned thrust systems, Thrust Tectonics Conference, Paper 18, p 45. Geology 870 Department, Royal Holloway University of London, Egham, England.

872 McClay, K. R., Whitehouse, P. S., Dooley, T. \& Richards, M. 2004. 3D evolution 873 of fold and thrust belts formed by oblique convergence. Marine and Petroleum 
876 McClay, K. R. \& Whitehouse, P. S. 2004. Analog Modeling of Doubly Vergent

877 Thrust Wedges. In: MCCLAY, K. (ed) Thrust tectonics and hydrocarbon systems. 878 AAPG Memoir, 82, 184-206.

879

880 Matte, P. 1968. La structure de la virgation hercynienne de Galice (Espagne).

881 Géologie Alpine, 44.

882

883 Matte, P. 2007. Variscan thrust nappes, detachments, and strike-slip faults in the 884 French Massif Central: Interpretation of the lineations. In: HATCHER JR., R.D., 885 Carlson, M.P., McBride, J.H. \& Martínez Catalán, J.R. (eds), 4-D Framework of 886 Continental Crust. Geological Society of America, Memoir, 200, 391-402. Doi: 887 $10.1130 / 2007.1200(20)$

888

889 MolLI, G. 2008. Northern Apennine-Corsica orogenic system: an updated overview. 890 In: Siegesmund, S., Fugenschun, B. \& Froitzheim, N. (eds) Tectonic Aspects of the 891 Alpine-Dinaride-Carpathian System. Geological Society, London, Special 892 Publications, 298, 413-442

893

894 Moldi, G. \& VASElli, L. 2006. Structures, interference patterns and strain regime 895 during mid-crustal deformation in the Alpi Apuane (Northern Apennine, Italy), 896 Geological Society of America, Special Paper, 414, 79-93 897

898 Molli, G., Giorgetti, G. \& Meccheri, M. 2002. Tectono-metamorphic evolution of 
899 the Alpi Apuane Metamorphic Complex: new data and constraints for geodynamic 900 models. Bollettino della Società Geologica Italiana, volume speciale n.1, 789-800.

901

902 Mosar J. 1999. Present-day and future tectonic underplating in the Western

903 SwissAlps: reconciliation of basement/wrench-faulting and décollement folding of the 904 Jura and Molasse Basin in the Alpine foreland. Earth and Planetary Science Letters, $905 \mathbf{1 7 3 / 3}, 143-155$.

906

907 Mugnier, J. L., Baby, P., Colletta, B., Vinour, P., Bale, P. \& Leturmy, P. 1997.

908 Thrust geometry controlled by erosion and sedimentation: A view from analogue 909 models. Geology, 25, 427-430.

910

911 Mulugeta, G. 1988. Modelling the geometry of Coulomb thrust wedges. Journal of

912 Structural Geology, 10, 847-859.

913

914 Mulugeta, G. \& KoYi, H. 1992. Episodic accretion and strain partitioning in a model 915 sand wedge. Tectonophysics, 202, 319-333.

916

917 Nelson, K. D., et al. 1996. Partially molten middle crust beneath southern Tibet:

918 Synthesis of project INDEPTH results, Science, 274, 1684-1688, 919 doi:10.1126/science.274.5293.1684.

920

921 Nicolas, A., Bouchez, J. L., Blaise, J. L. \& Poirier, J. P. 1977. Geological aspects 922 of deformation in continental shear-zones. Tectonophysics, 42, 55-73, doi: 923 10.1016/0040-1951(77)90017-8. 
925 Nieuwland, D. A., Leutscher, J. H. \& Gast, J. 2000. Wedge equilibrium in fold926 and-thrust belts: prediction of out-of-sequence thrusting based on sandbox 927 experiments and natural examples. Netherlands Journal of Geosciences, 79, 81-91.

928

929 Noble, T. E. \& DixOn, J. M. 2011. Structural evolution of fold-thrust structures in 930 analog models deformed in a large geotechnical centrifuge. Journal of Structural 931 Geology, 33, 62-77

932

933 Pérez-Estàun, A., Martinez-Catalan, J. R. \& Bastida, F. 1991. Crustal 934 thickening and deformation sequence in the footwall to the suture of the Variscan belt 935 of NW Spain. Tectonophysics, 191, 243-253

936

937 Persson, K. S. \& Sokoutis, D. 2002. Analogue models of orogenic wedges 938 controlled by erosion. Tectonophysics, 356, 323-336.

939

940 Platt, J. P., Leggett, J. K., Young, J., RaZA, H. \& Alam, S. 1985. Large-scale 941 sediment underplating in the Makran accretionary prism, southwest Pakistan: 942 Geology, 13, 507-511.

943

944 Price, R. A. 1981. The Cordilleran foreland thrust and fold belt in the southern 945 Canadian Rocky Mountains. In: McClay, K. \& PriCE, N.J. (eds) Thrust and nappe 946 tectonics. Geological Society, London, Special Publication, 9, 427-448.

948 RAmberg, H. 1981. Gravity, deformation and the earth's crust, 2nd edition, 
RANALLI, G. 1995. Rheology of the Earth, 2nd edition, Chapman \& Hall, London.

Schellart, W. P. 2000. Shear test results for cohesion and friction coefficients for

954 different granular materials: scaling implications for their usage in analogue 955 modelling. Tectonophysics, 324, 1-16

956

SchöPfER, M. P. J. \& ZULAUF, G., 2002. Strain dependent rheology and the memory 958 of plasticine. Tectonophysics, 354, 85-99.

959

960 Simancas, J. F., Ayarza, P., Azor, A., Carbonell, R., Martinez Poyatos, D.,

961 Pérez-Estàun, A., Gonzalez Lodeiro, F. A. A seismic geotraverse across the 962 Iberian Variscides: orogenic shortening, collisional magmatism and orocline 963 development. Tectonics, in press, doi : 10.1002/tect.20035

964

965 Smit, J., Burg, J.-P., Dolati, A. \& Sokoutis, D. 2010. Effects of mass waste events 966 on thrust wedges: Analogue experiments and application to the Makran accretionary 967 wedge. Tectonics, 29. TC3003, doi : 10.1029/2009TC002526

968

969 Soula, J. C., Debat, P., Brusset, S., Bessière, G., Christophoul, F. \& Déramond, 970 J. 2001. Thrust-related, diapiric, and extensional doming in a frontal orogenic wedge:

971 Example of the Montagne Noire, Southern French Hercynian Belt. Journal of 972 Structural Geology, 23, 1677-1699, doi:10.1016/ S0191-8141(01)00021-9. 
974 Stockmal, G. S., Beaumont, C., Nguyen, M. \& Lee, B. 2007. Mechanics of thin975 skinned fold-and-thrust belts: Insights from numerical models. In: SEARS, J.W., 976 HARMs, T. A. \& EVEnCHICK, C. A. (eds) Whence the Mountains? Inquiries into the 977 evolution of orogenic systems: A volume in Honor of Raymond A. Price. Geological 978 Society of America, Special Paper, 433, 63-98.

979

980 Storti, F. \& MCClay, K. 1995. Influence of syntectonic sedimentation on thrust 981 wedges in analogue models. Geology, 23, 999-1002.

982

983 Sutton, J. \& Watson, J. V. 1986. Architecture of the continental lithosphere.

984 Philosophical Transactions of the Royal Society, London, A317, 5-12.

985

986 Tikof, B. \& Peterson, K. 1998. Physical experiments of transpressional folding. 987 Journal of Structural Geology, 20, 661-672

988

989 Van Den Driessche, J. \& Brun, J. P. 1992. Tectonic evolution of the Montagne 990 Noire (french Massif Central): a model of extensional gneiss dome: Geodinamica 991 Acta, 5, 85-99.

992

993 Webb, A. A. G., Yin, A., Harrison, T. M., Celerier, J. \& Burgess, W. P. 2007. The 994 leading edge of the Greater Himalayan Crystalline complex revealed in the NW 995 Indian Himalaya: Implications for the evolution of the Himalayan orogen, Geology, 996 35, 955-958, doi:10.1130/G23931A.1.

997

998 Webb, A. A. G., Schmitt A. K., He, D. \& Weigand E.L. 2011. Structural and 
999 geochronological evidence for the leading edge of the Greater Himalayan Crystalline 1000 complex in the central Nepal Himalaya. Earth and Planetary Science Letters, 304, $1001 \quad 483-495$.

1002

1003 Zulauf, J. \& Zulauf, G. 2004. Rheology of plasticine used as rock analogue: the 1004 impact of temperature, composition and strain. Journal of Structural Geology, 26, $1005 \quad 725-737$.

1006 
Figures and Captions

1008

\begin{tabular}{|c|c|c|c|c|c|c|c|c|c|c|c|c|}
\hline \multirow{2}{*}{$\begin{array}{l}\text { Experiment } \\
\text { name }\end{array}$} & \multirow{2}{*}{$\begin{array}{c}\text { Total } \\
\text { shortening } \\
(\mathrm{cm})\end{array}$} & \multicolumn{2}{|c|}{ Protowedge } & \multicolumn{2}{|c|}{ Lower plate } & \multirow{2}{*}{$\begin{array}{l}\text { Decollement } \\
\text { position* } \\
\text { (cm) }\end{array}$} & \multicolumn{3}{|c|}{ Plastiline } & \multicolumn{3}{|c|}{ Erosion } \\
\hline & & $\begin{array}{l}\text { Length } \\
(\mathrm{cm})\end{array}$ & $\begin{array}{l}\text { Slope } \\
\left({ }^{\circ}\right)\end{array}$ & $\begin{array}{l}\text { Total thickness } \\
\qquad(\mathrm{cm})\end{array}$ & Termination & & Present & $\begin{array}{c}\text { Thickness } \\
(\mathrm{cm})\end{array}$ & $\begin{array}{l}\text { Position* } \\
\text { (cm) }\end{array}$ & Present & $\begin{array}{l}\text { Start }{ }^{\dagger} \\
(\mathrm{cm})\end{array}$ & Slope \\
\hline $\operatorname{Exp} 1$ & 150 & 61 & 7 & 3.1 & Straight & Top lower plate & No & & & No & & \\
\hline Exp 2 & 150 & 66 & 4 & 3.1 & Straight & Top lower plate & No & & & No & & \\
\hline Exp 3 & 160 & 80 & 2 & 3.1 & Gradual & Top lower plate & No & & & No & & \\
\hline Exp 4 & 180 & 74 & 0 & 3.1 & Straight & 1.1 & No & & & No & & \\
\hline $\operatorname{Exp} 5$ & 201 & 74 & 0 & 3.1 & Straight & 1.1 & No & & & Yes & 30 & Variable \\
\hline Exp 6 & 198 & 66 & 4 & 3.1 & Straight & 2.1 & No & & & Yes & 30 & Variable \\
\hline $\operatorname{Exp} 7$ & 220 & 66 & 4 & 3.1 & Straight & 2.1 & No & & & Yes & 20 & Fixed $\left(5^{\circ}\right)$ \\
\hline $\operatorname{Exp} 8$ & 160 & 80 & 2 & 3.3 & Gradual & Top lower plate & Yes & 0.3 & 1.7 & No & & \\
\hline $\operatorname{Exp} 9$ & 167 & 90 & 0 & 3.3 & Gradual $(-15 \mathrm{~cm}) \ddagger$ & Top lower plate & Yes & 0.2 & 1 & No & & \\
\hline Exp 10 & 163 & 90 & 0 & 3.3 & Gradual $(-15 \mathrm{~cm}) \ddagger$ & Top lower plate & Yes & 0.1 & 1 & No & & \\
\hline Exp 11 & 193 & 90 & 0 & 3.3 & Gradual $(-15 \mathrm{~cm}) \ddagger$ & Top lower plate & Yes & 0.1 & 1 & Yes & 25 & Fixed $\left(5^{\circ}\right)$ \\
\hline Exp 12 & 175 & 80 & 2 & 3.3 & Gradual & 1.48 & Yes & 0.2 & 1.5 & No & & \\
\hline Exp 13 & 200 & 90 & 0 & 3.5 & Gradual $(-15 \mathrm{~cm}) \ddagger$ & 1 & Yes & 0.1 & 1.7 & Yes & 15 & Fixed $\left(3^{\circ}\right)$ \\
\hline
\end{tabular}

Notes:

* Height from base plate

+ Amount of initial shortening without erosion

¥ Lower plate ends before the backstop

1009

1010 Table 1. Parameters used for the thirteen experiments. (Models described in the text are in bold) 


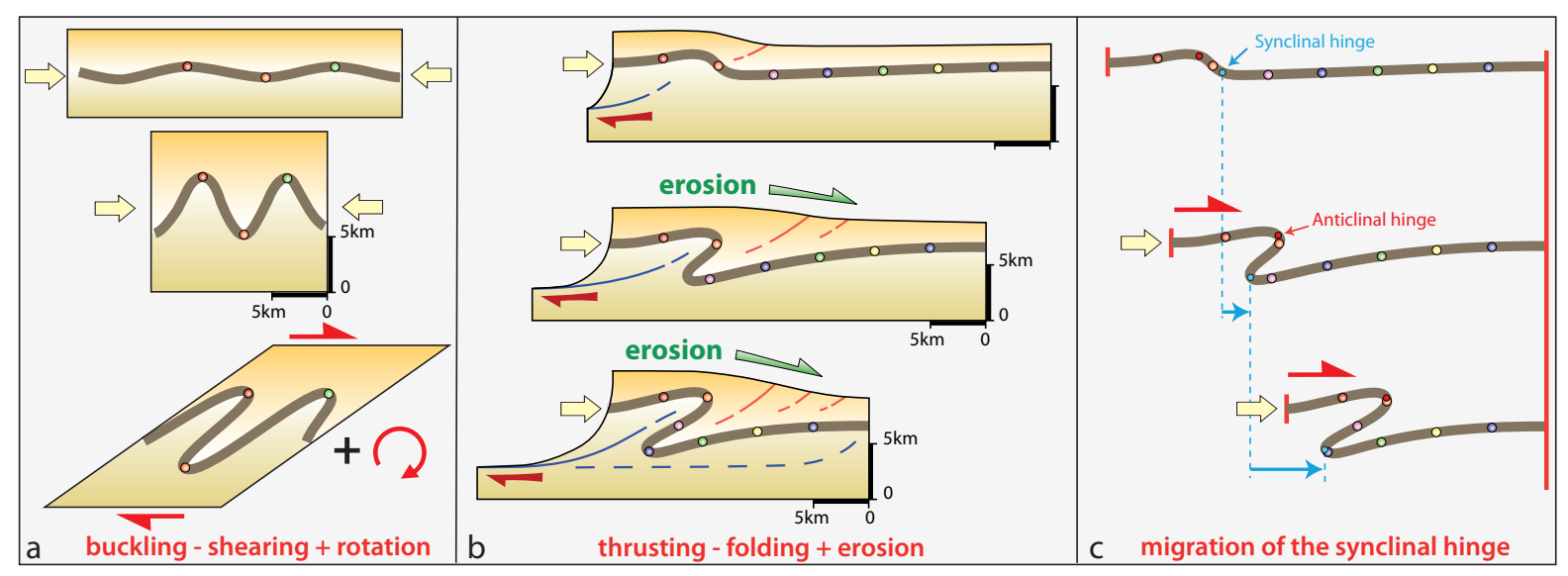

1013

1014 Fig. 1. Cartoon showing two folding mechanisms to generate large-scale overturned

1015 folds in fold and thrust belts. The first mechanism involve an important burial

1016 whereas the second one allows the development of large folds with slight burial. (a)

1017 Buckling and folding during compressional shortening followed by shearing and

1018 tilting of fold limbs; (b) Fold amplification by thrusting and subsequent shearing,

1019 unrolling and migration of the synclinal hinge in the frame of a fold and thrust wedge;

1020 (c) Simplified kinematic sketch of the same process. Coloured circles are passive

1021 markers regularly spaced in the folded layer.

1022

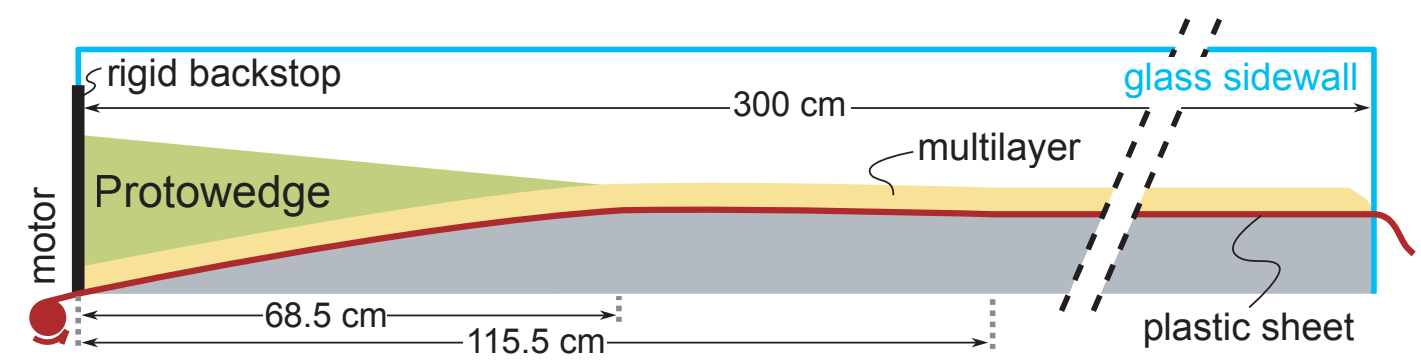

Fig. 2. Experimental set-up. The width of the device is $10 \mathrm{~cm}$. 


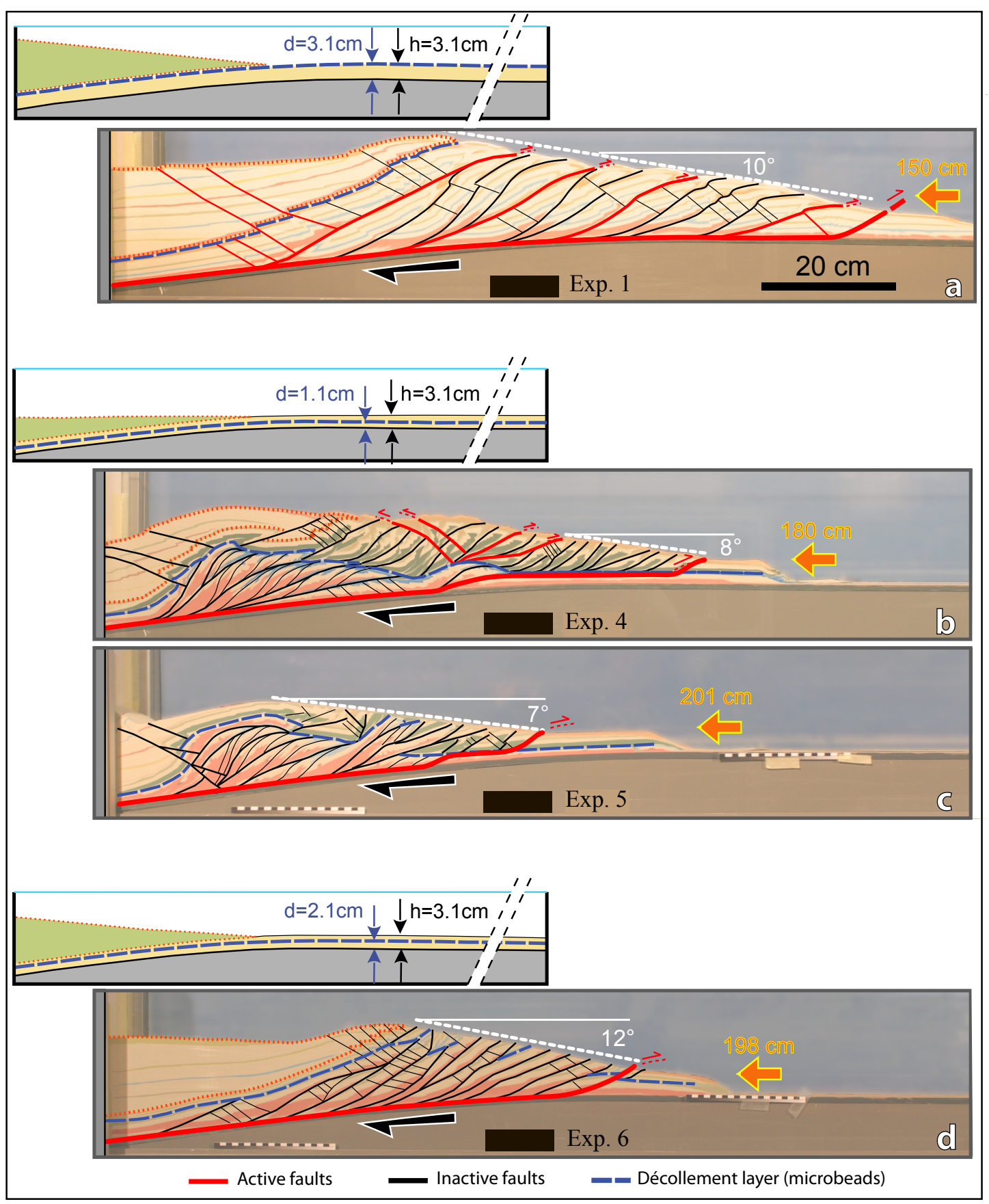

Fig. 3. Initial configuration and final result of models involving a microbeads layer

1028 located at different heights ("d" on sketch). (a) Classical high friction thrust wedge.

1029 The thrust front propagates in a piggy-back style, but some faults remain active after

1030 the nucleation of new faults at the front. (b) Strain partitioning: duplexing at the base

1031 of the wedge and frontal accretion at the toe. Note the cyclical behavior of

1032 underplating. (c) Impact of surface erosion on the wedge dynamics, location of 
1033 underplating and exhumation of underplated units. (d) Underplating is inhibited when

1034 décollement is too shallow. Shortening in $\mathrm{cm}$ on digital screen.

1035

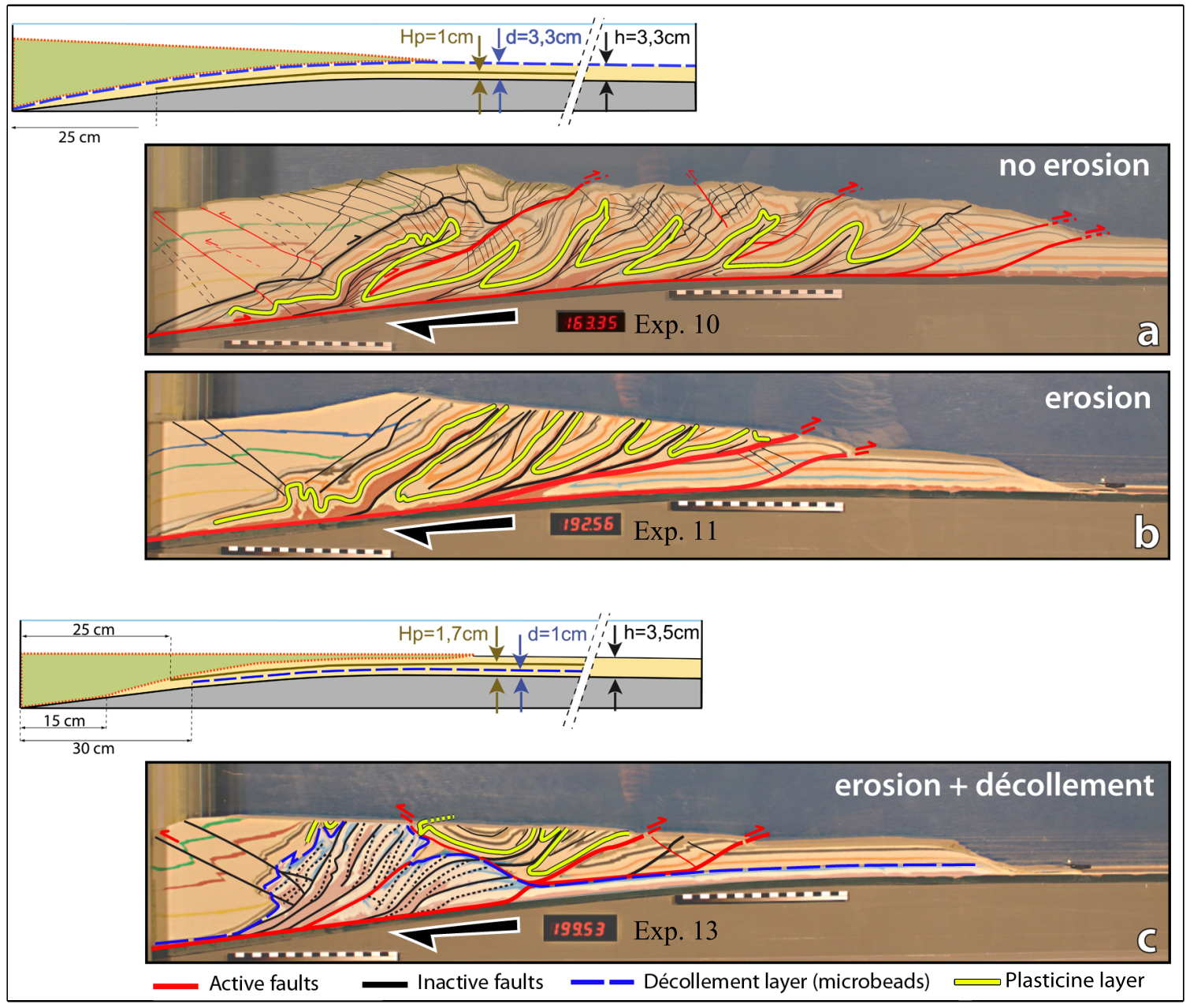

1036

1038

1039

1040

1041

1042

Fig. 4

Fig. 4. Initial setting and final stage of model involving a thin layer of plasticine (Hp:

Height of the plasticine layer on sketch). (a) Case no erosion. Folds are overturned with an angle between $30^{\circ}$ and $50^{\circ}$; (b) Same experiment with erosion; (c) Brittle/plastic model with décollement layer and erosion. Shortening in $\mathrm{cm}$ on digital screen. 


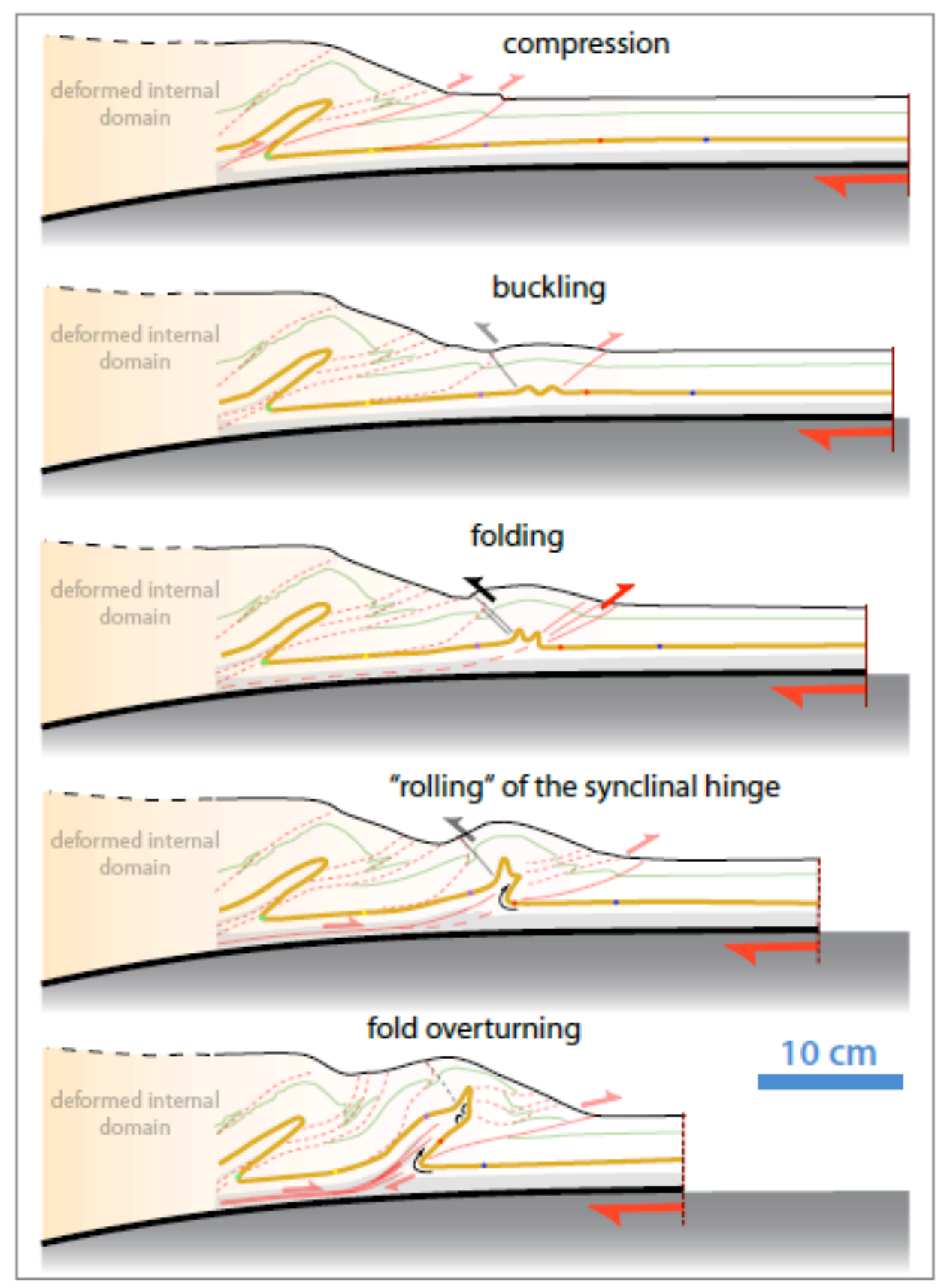

1044 Fig. 5. Kinematic model of folding. The thick line with circles represents the 1045 plasticine with displacement indicators. 

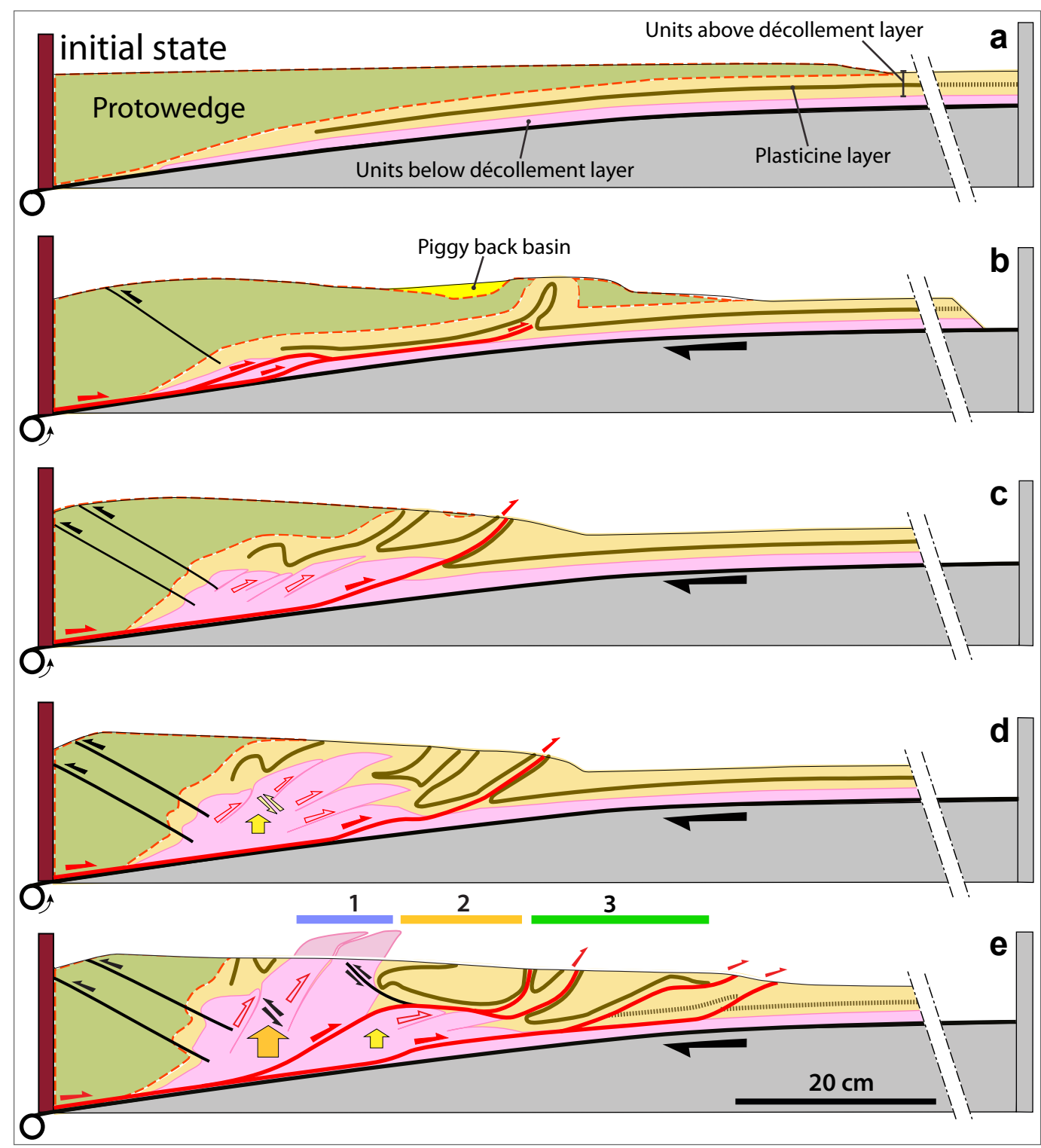

Fig. 6. Evolution of complex model involving brittle/plastic multilayer, erosion and

1049 décollement layer. Upper units situated above décollement layer are composed of

1050 sand and plasticine; deep units below décollement layer are composed of sand. At the

1051 final stage (e), three domains are juxtaposed: (1) exhumation of deep rocks, (2) the

1052 domain of recumbent folds and (3) the overturned folds. 


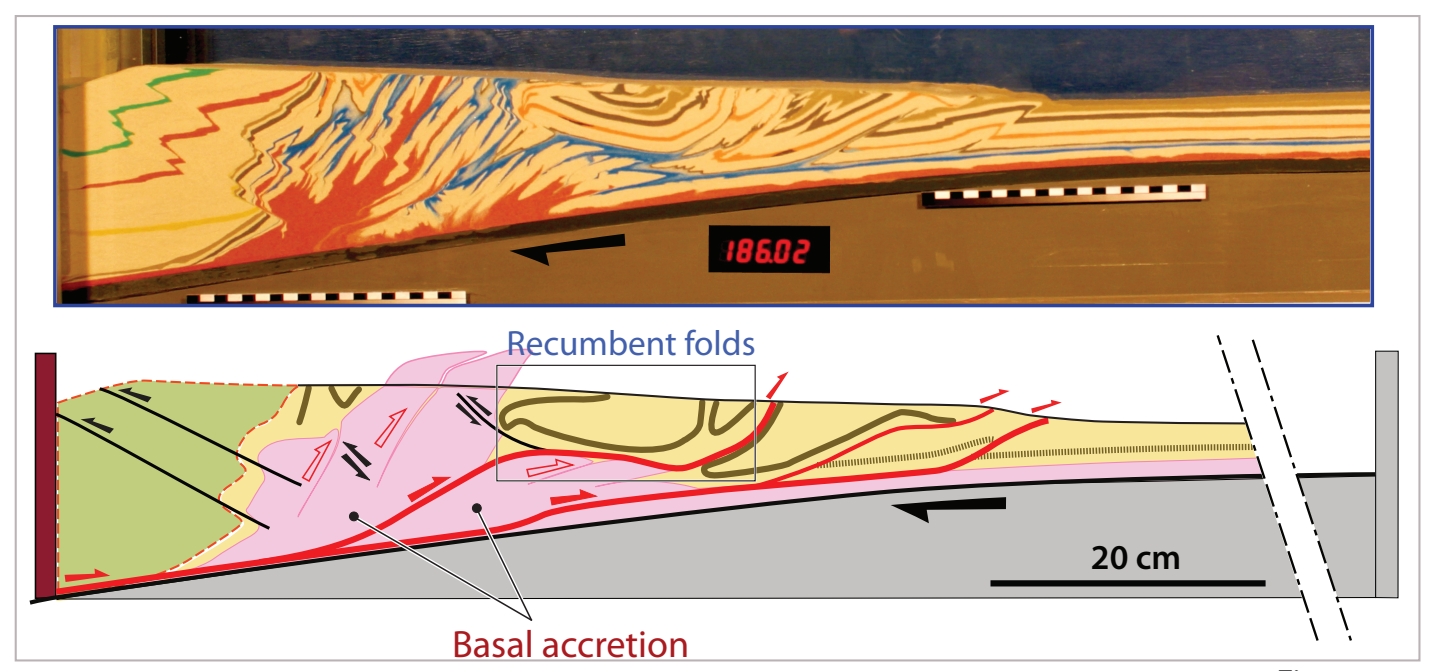

Fig.7

1054 1055

1056 1057

Fig. 7. Relationships between cyclical duplexing and kinematics of folding in a brittle/plastic model with erosion and décollement level.

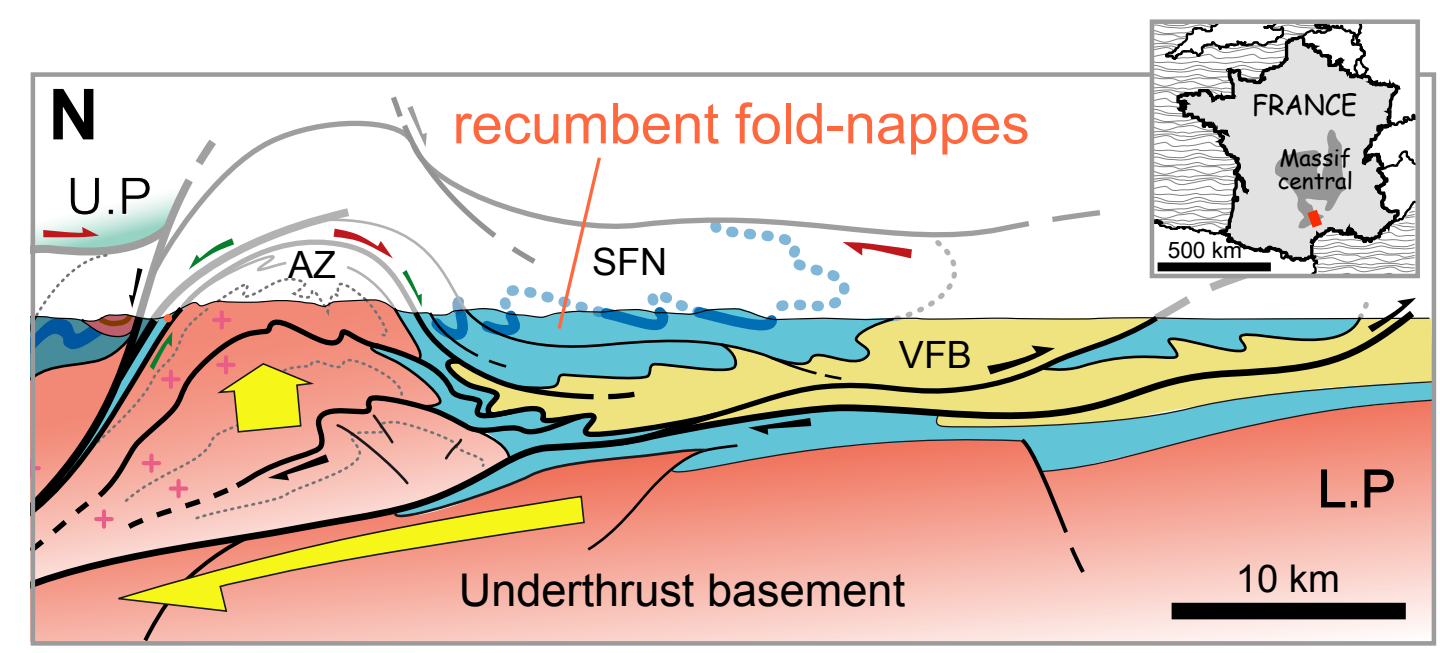

Fig. 8

1058

1059

1060 (modified from Malavieille 2010). U.P.: Upper Plate, L.P.: Lower Plate. AZ: Axial

1061 Zone, SFN: Southern Fold Nappes, VFB: Visean Foreland Basin. 


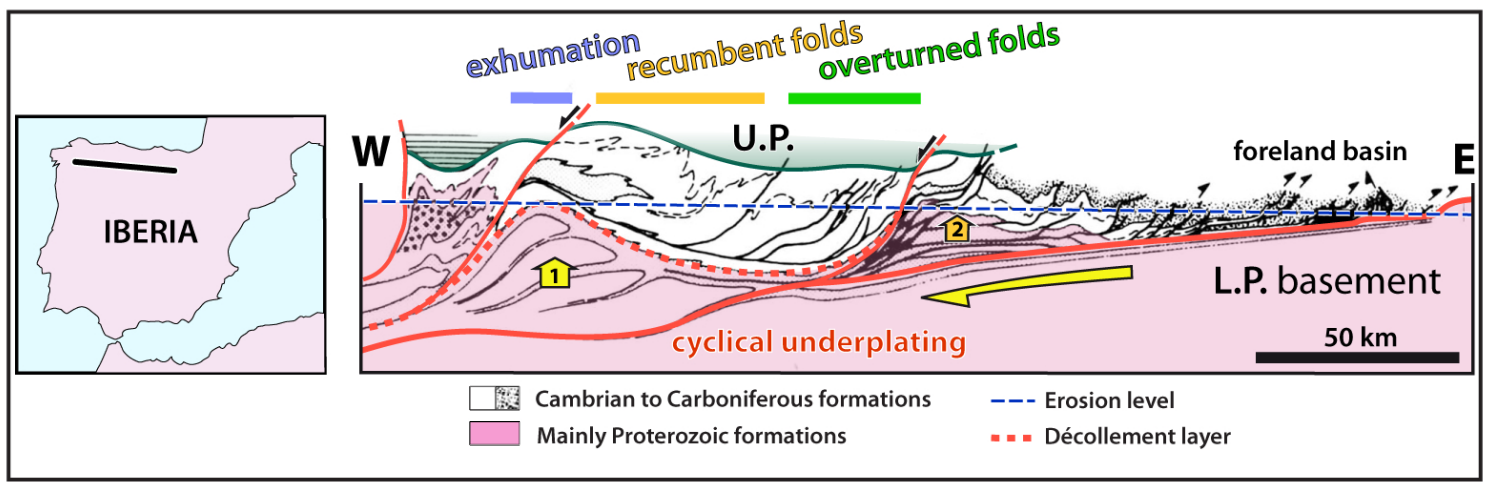

1064 Fig. 9. Cross-section of Variscan Belt in Galicia, Spain (modified from Pérez-Estàun 1065 et al. 1991). U.P.: Upper Plate; L.P.: Lower Plate.

1066

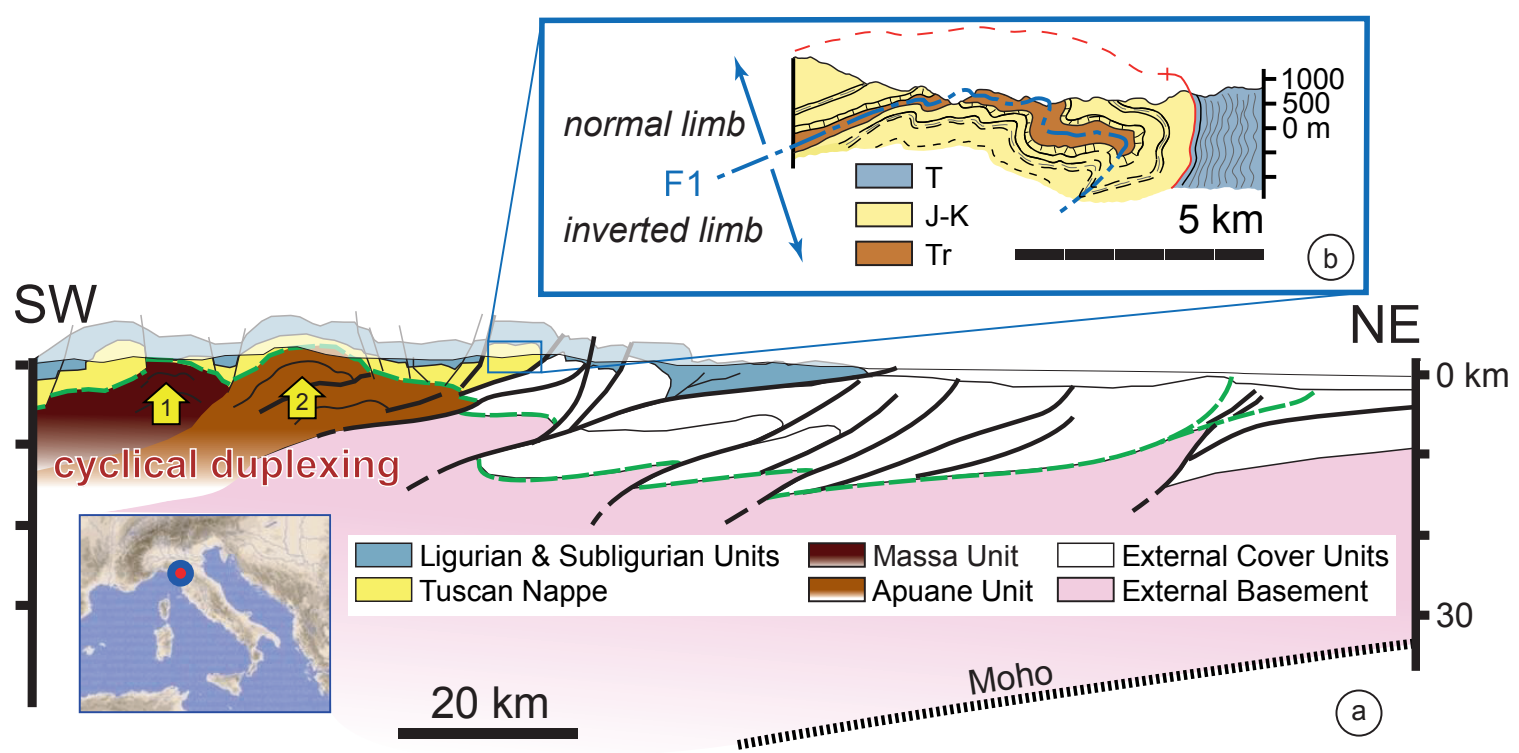

1067

1068

1069

1070

Fig. 10. (a) Cross section of the Northern Apennines, Italy (modified from Molli

Fig. 10 